\title{
The UK and German Low-Carbon Industry Transitions from a Sectoral Innovation and System Failures Perspective
}

\author{
Konstantinos Koasidis ${ }^{1}\left(\mathbb{D}\right.$, Alexandros Nikas ${ }^{1, *} \mathbb{C D}$, Hera Neofytou $^{1}{ }^{(\mathbb{D}}$, \\ Anastasios Karamaneas ${ }^{1}\left(\mathbb{D}\right.$, , Ajay Gambhir ${ }^{2} \mathbb{D}$, Jakob Wachsmuth ${ }^{3}$ and Haris Doukas ${ }^{1}$ \\ 1 Decision Support Systems Laboratory, School of Electrical and Computer Engineering, \\ National Technical University of Athens, Iroon Politechniou 9, 15780 Athens, Greece; \\ kkoasidis@epu.ntua.gr (K.K.); hneofytou@epu.ntua.gr (H.N.); akaramaneas@epu.ntua.gr (A.K.); \\ h_doukas@epu.ntua.gr (H.D.) \\ 2 Imperial College London, Grantham Institute, London SW7 2AZ, UK; a.gambhir@imperial.ac.uk \\ 3 Fraunhofer Institute for Systems and Innovation Research, 76139 Karlsruhe, Germany; \\ jakob.wachsmuth@isi.fraunhofer.de \\ * Correspondence: anikas@epu.ntua.gr; Tel.: +30-210-772-3612
}

Received: 19 August 2020; Accepted: 21 September 2020; Published: 23 September 2020

\begin{abstract}
Industrial processes are associated with high amounts of energy consumed and greenhouse gases emitted, stressing the urgent need for low-carbon sectoral transitions. This research reviews the energy-intensive iron and steel, cement and chemicals industries of Germany and the United Kingdom, two major emitting countries with significant activity, yet with different recent orientation. Our socio-technical analysis, based on the Sectoral Innovation Systems and the Systems Failure framework, aims to capture existing and potential drivers of or barriers to diffusion of sustainable industrial technologies and extract implications for policy. Results indicate that actor structures and inconsistent policies have limited low-carbon innovation. A critical factor for the successful decarbonisation of German industry lies in overcoming lobbying and resistance to technological innovation caused by strong networks. By contrast, a key to UK industrial decarbonisation is to drive innovation and investment in the context of an industry in decline and in light of Brexit-related uncertainty.
\end{abstract}

Keywords: United Kingdom; Germany; systems of innovation; sectoral innovation systems; system failures; industrial transitions

\section{Introduction}

Being responsible for the production of all goods used in people's lives, industry lies at the heart of an economy. Its processes, however, are associated with high amounts of energy used, especially from fossil fuels, thereby resulting in high GHG emissions. Industry accounts for 30\% of worldwide direct and indirect emissions, while direct and industrial process-related $\mathrm{CO}_{2}$ emissions account for almost $60 \%$ of total industrial share [1]. Industry has been a major emitter in Europe, accounting for over $20 \%$ of total emissions, including indirect emissions, more than $25 \%$ of which are process-related [2]. Among the most energy-intensive sectors with the highest contributions to industrial GHGs are iron and steel, cement and chemicals. The heterogeneous sector requires critical consideration of industrial systems in a holistic manner to understand the complex political economy, concerns by different actors over leakage and the large quantity of free allowances, as well as the desire for strong industrial policies, especially for technologies with increased attention, like CCS and hydrogen. Industrial decarbonisation is therefore critical to decarbonising the European economy [3]. 
Indicatively, $4-7 \%$ (this range seems to reflect the consensus in various sources. Different installations behave differently regarding $\mathrm{CO}_{2}$ emissions despite using the same technologies (e.g., fuel quality), making it difficult to calculate a percentage) of global industrial $\mathrm{CO}_{2}$ emissions derive from the iron and steel industry $[4,5]$, highlighting the importance of alternative production technologies in the sector. However, large-scale transitions encounter many challenges, since investing in relevant technological innovations is considered expensive and risky [6], due to possible production failures potentially damaging companies' market shares [7]. Having gone through various sociotechnical shifts that established dominant processes, and considering innovation costs, this industry may feature technological lock-ins hindering economy-wide energy transitions [8].

Cement production has also been central in economic growth of developed countries [9]. Accounting for almost 15\% of global industrial energy demand, cement-related activities are considered energy-intensive [10]. $\mathrm{CO}_{2}$ emissions are driven by processes associated with raw materials, regardless of the combusted fuel. These account for approximately 50\% of total cement GHG emissions, and 5\% of global $\mathrm{CO}_{2}$ emissions [11]. Significant transformations are therefore required.

The chemical and petrochemical industry is another important contributor to industrial GHG emissions (7\% globally), accounting for $10 \%$ of global total final energy consumption. Encompassing a very diverse range of products, the sector lies in the boundaries between energy- and non-energy-intensive [12].

This review focuses on the industrial sectors of Germany and the United Kingdom (UK), as two exemplifying countries that have historically been among the largest European industries with significant emissions but different development, especially in recent years. Germany's industry shows stability, with iron and steel playing an important role in supplying other sectors like the automotive industry. Compared to Germany, the UK shows a significant shift from these energy-intensive industries towards services $[13,14]$. These differences may provide insights into the elements of each system promoting or hindering decarbonisation.

Innovation, whether technological or organisational [15], usually lies at the core of sociotechnical change, displaying systemic nature [16]. Systems of Innovation allow a holistic and interdisciplinary perspective [17] that captures the role of actors, networks, institutions and learning processes in innovation diffusion [18]. We choose the Sectoral Innovation System (SIS) framework [19], as a basis of our methodological approach, to examine the multidimensional dynamics [20] of industry, aiming to identify the role of different actors in driving transition towards carbon lock-out in energy-intensive industries [21]. Comparison is further elaborated via the system failure framework [22], to investigate potential barriers to diffusion of low-carbon industrial processes.

Our aim is to review the German and UK industrial systems, focusing mainly on iron and steel, cement and chemicals, which are the dominant industrial sectors in the activities of the two countries, from a low-carbon transition perspective, while examining barriers possibly hindering use and diffusion of sustainable industrial technologies, building on and integrating the SIS and system failures frameworks. Eventually, these insights can be translated into policy implications for fostering the industrial transition under the European Green Deal. We find that relaxation of emission regulations due to concerns about international competitiveness has led to policy and institutional inconsistencies in both countries, thereby acting as a bottleneck for innovative technologies allowing the regime to retain currently energy-intensive processes. Accordingly, recent emission cuts in energy-intensive industries are attributed to shrinking activity and, to a small extent, to carbon intensity cuts, implying low diffusion of low-carbon technologies in these sectors. We thus argue that deindustrialisation of UK economy has weakened the regime, providing opportunities for businesses with innovative processes to grow, given existing interest in green technologies like hydrogen and CCS. This does not apply to Germany whose strong network of companies threatens to slow down innovation.

Section 2 presents background information about the countries and sectors examined, while Section 3 outlines the theoretical framework of the study. Sections 4 and 5 provide an overview of the two SIS. Section 6 assesses the structural failures of the two countries, while Section 7 discusses 
findings and concludes the review. An overview of the technologies currently used in the three sectors is provided in the Appendix A.

\section{Background}

Germany is considered a great economic power having the highest GDP in Europe and the 4th largest GDP globally [23]. Its economy is mainly based on services (62\% of GDP), followed by the industrial sector (27\% of GDP) [24]. Germany ranks 6th among 130 countries in the Green Economy Perception Index 2018, which records performance across leadership and climate change, efficiency, markets and investment, and environment [25]. The UK also has a strong economy, featuring the second highest GDP in Europe and the 6th worldwide, relying more on services (71\% of GDP) than on industry (18\% of GDP) [24], compared to Germany. In the Green Economy Perception Index 2018, the UK ranks 11th. The two countries also spend 3\% and 1.6\% of their GDP respectively in public and private research and development (R\&D) [26]. Germany and the UK are among the world's top 10 and $20 \mathrm{CO}_{2}$ emitters, respectively. From 1990 until 2017, industry accounted approximately for $24 \%$ of final energy consumption in Germany and $21 \%$ in the UK [27]. Figure 1 provides the two countries' industrial energy mix with natural gas and electricity having the highest contributions, while coal shows a decreasing trend. Electricity and heat refer to quantities purchased from energy companies. The steady levels in both countries, during the last decade, indicate the necessity for policy initiatives to trigger deep transformative change, while also mitigating GHG emissions, which have increased in Germany in the last years and have not adequately dropped in the UK (Figure 2).

Regarding total manufacturing industrial emissions, Germany and the UK reduced GHG emissions by $30 \%$ and $46 \%$ in 2018, compared to 1990 [28]. This can be partially attributed to UK economy shifting away from manufacturing to service-based industries (Figure 3), showing decreased direct emissions, while Germany's industrial share remained stable in recent years, despite post-unification industrial downturn in Eastern Germany (Figure 2). The sector's GHG emissions contribute to the national footprint (excluding LULUCF) of each country with $15 \%$ and $10 \%$ for Germany and the UK respectively [28]. It is noteworthy that the UK government published its Clean Growth Strategy (CGS) in October 2017, setting out ambitious goals and proposals regarding pathways up to 2032. UK's Industrial Strategy was also published in November 2017, including a Clean Growth Grand Challenge targeted at helping its industry benefit from global shift to decarbonisation. The CGS stipulates investments of $€ 115$ million for industrial decarbonisation and CCS. Similarly, in Germany, the federal government's 2010 Energy Concept set the goal for reducing GHG emissions by at least $55 \%$ by 2030 , compared to 1990 - corresponding to a $49-51 \%$ cut in industry. With industry partly driven by the EU Emissions Trading System (ETS), a cost-effective scheme for adopting new technologies to address climate change [29], and carbon prices expected to rise within the next few years in line with ratcheting up climate policy stringency, efforts towards industrial decarbonisation should be intensified so that the two countries can retain competitiveness.

In both countries, basic metals, including iron and steel, showed the largest energy consumption in 2017, followed by chemicals; next were non-metallic minerals, including cement [27]. In Germany, there is almost stable energy consumption in all sectors, except for a drop in 2009 related to the global recession, with consumption however returning to previous levels in 2010. Instead, UK's industrial consumption has been constantly decreasing since 2000, marking an overall reduction of almost $47 \%$, reflecting a long-lasting transition from manufacturing towards services, with production of iron, steel and cement decreasing in the past twenty-five years-the latter by $50 \%$ [30]. Despite final demand providing a key explanation for the shift to services in advanced economies [31], to observe the phenomenon in the UK case we need to focus on productivity metrics (Figure 3). In 1970, services accounted for almost $56 \%$, while manufacturing accounted for $30 \%$ of the gross value added in the UK. The share of services significantly increased, reaching almost $80 \%$ by 2016 , with manufacturing suppressed to only $10 \%$ in the same year. 


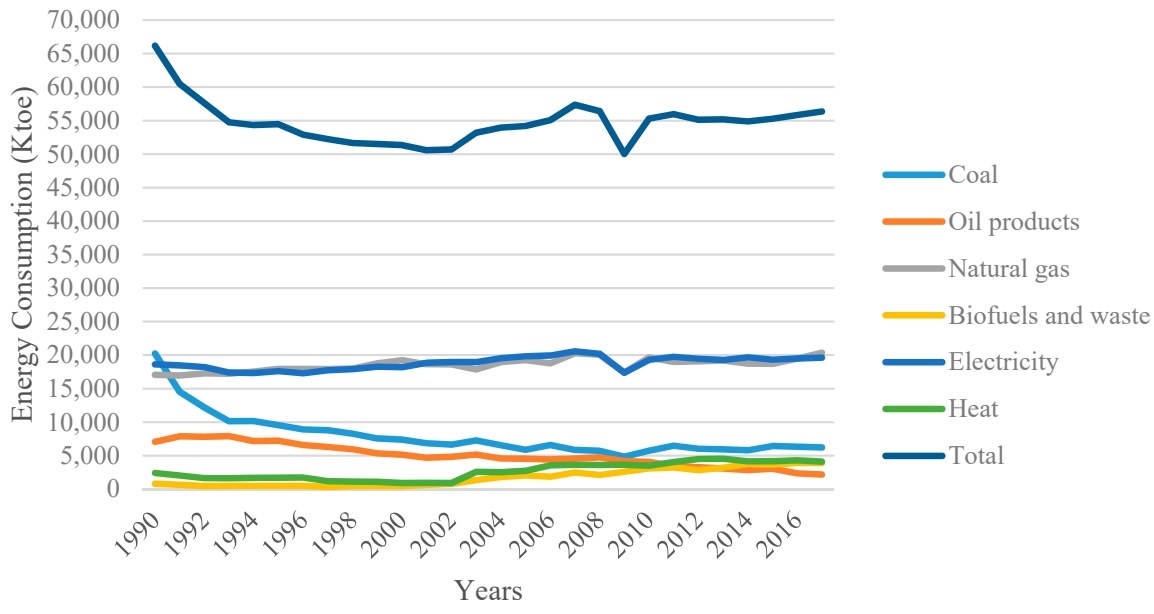

(a) Germany

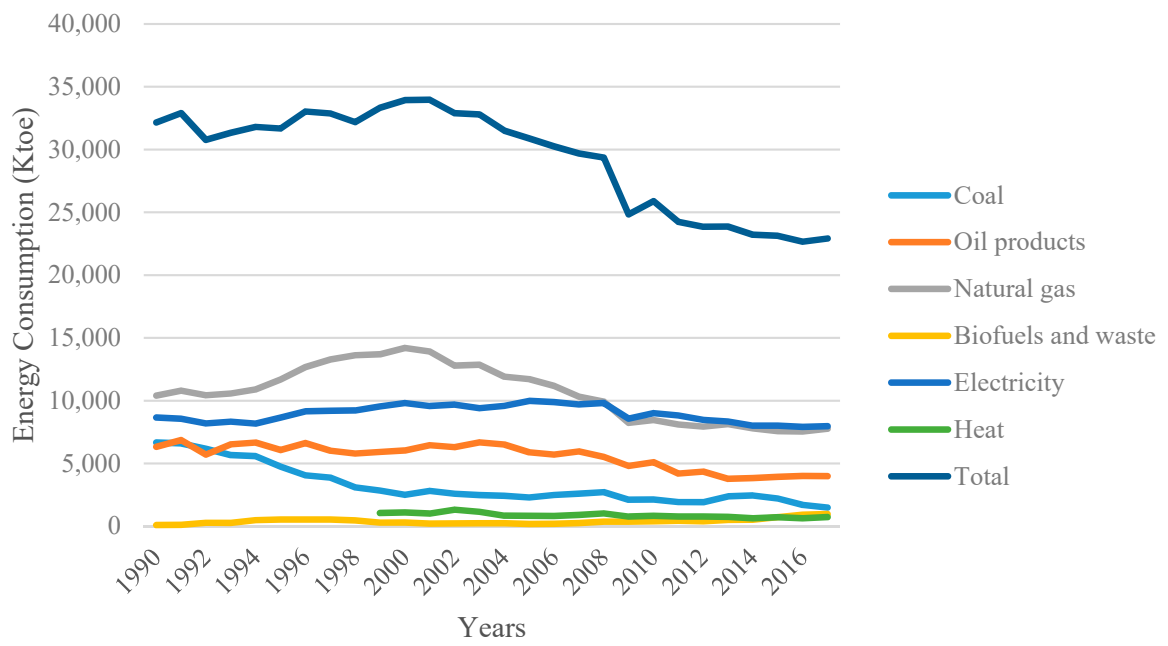

(b) UK

Figure 1. Industrial energy consumption per energy source in (a) Germany, and (b) the UK Source: [27], own elaboration.

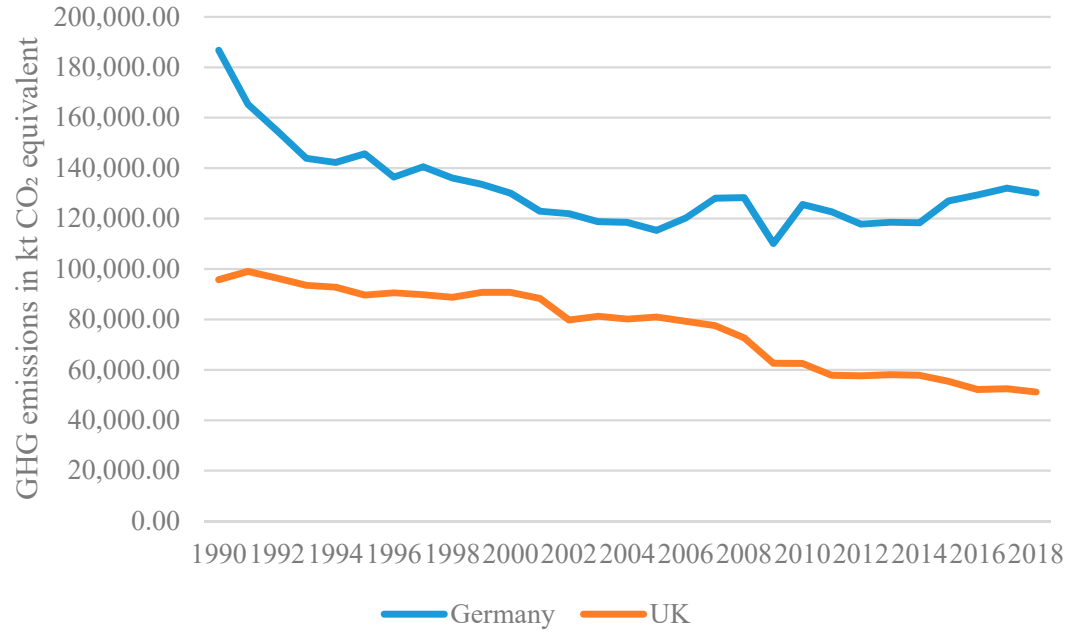

Figure 2. GHG emissions from Manufacturing Industries and Construction in Germany and the UK from 1990 to 2018. Source: [28], own elaboration. 


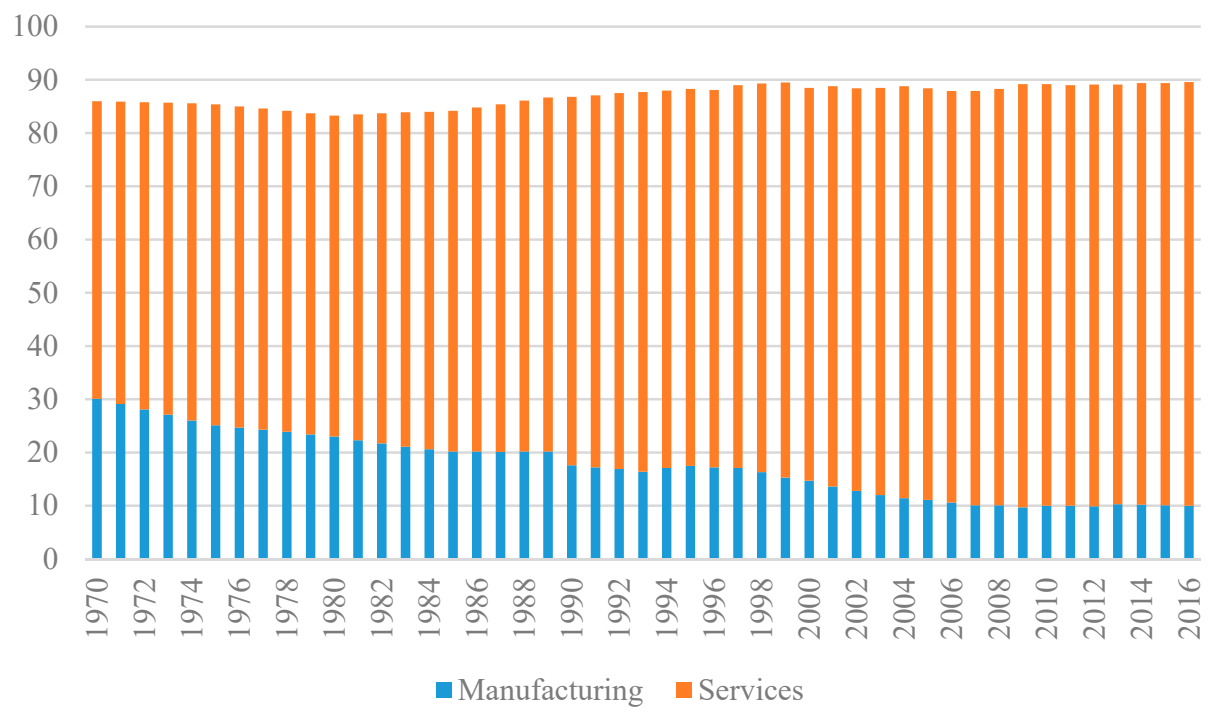

Figure 3. Manufacturing and services gross value added (GVA) shares in the UK from 1970 to 2016. Source: [32], own elaboration.

For a clear distinction between activity effects and technological progress in the evolution of total $\mathrm{CO}_{2}$ emissions of an industrial sector, it is useful to decompose total emissions into $\mathrm{CO}_{2}$ emissions per economic output $\left(\mathrm{CO}_{2}\right.$ intensity) and economic activity [33]. $\mathrm{CO}_{2}$ intensity is driven by the specific energy consumption and fuel mix, covering both energy efficiency improvements and switch to cleaner fuels [34]. Below, an evaluation of both factors is presented, based on $\mathrm{CO}_{2}$ emissions and added value of each sector from the JRC-IDEES database [35], covering the period 2000-2015 (Figure 4).

Between 2000 and 2015, UK economic activity in iron and steel, basic chemicals and cement experienced mainly a downturn, with some relaxation recently. The same applies to the German cement sector, while basic chemicals saw substantial economic growth, apart from a modest downturn during the 2009 recession. Economic activity of German iron and steel increased strongly until a severe drop in 2009, stabilising at its starting point afterwards.

During the same period, $\mathrm{CO}_{2}$ intensity of German cement kept roughly constant; in the UK, it started out lower but increased to similar levels, while its iron and steel energy intensity saw high upward dynamics, particularly during the recession, returning to starting levels afterwards. $\mathrm{CO}_{2}$ intensity remained substantially lower in the German iron and steel sector throughout the period. Finally, $\mathrm{CO}_{2}$ intensity of the basic chemicals sector in the UK started out twice as high as in Germany but decreased by a quarter, with Germany's $\mathrm{CO}_{2}$ intensity not changing markedly.

In summary, there has been little progress in decarbonising these energy-intensive industries in either country. Recent emission reductions mainly result from reduced activity, except for the UK chemicals industry, where $\mathrm{CO}_{2}$ intensity substantially dropped. In contrast, cement $\mathrm{CO}_{2}$ intensity even increased. This lack of progress combined with the importance of the industrial sector in both countries creates the urgent need to formally study the sectoral innovation systems and failures in the two industries and reach policy implications that can help accelerate the envisaged transition. 


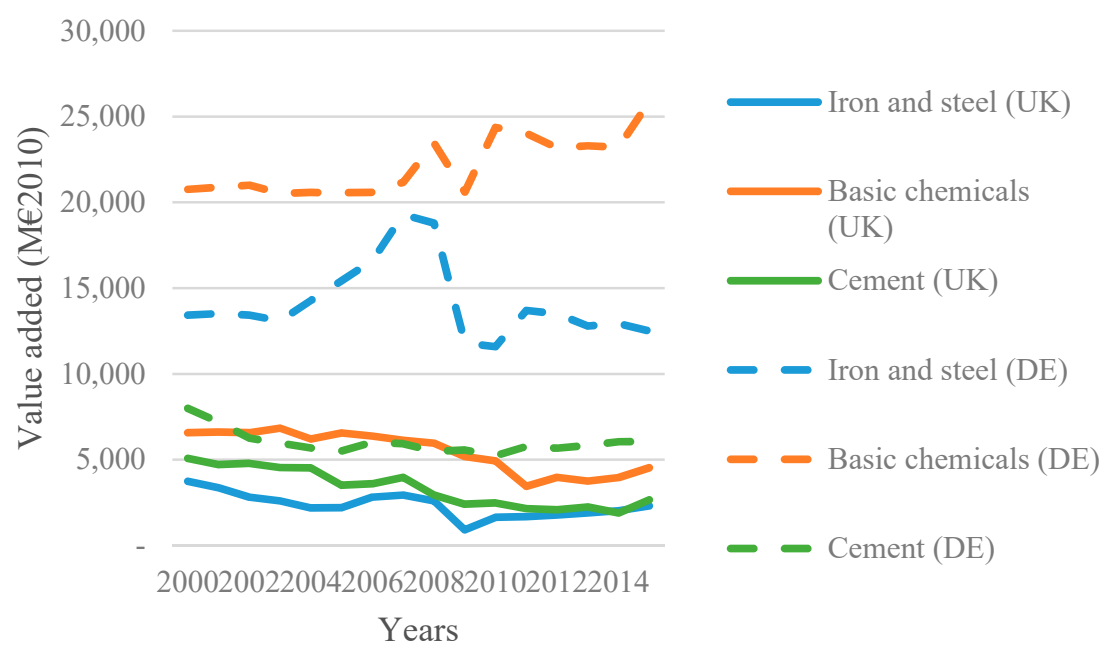

(a) Value added per sector

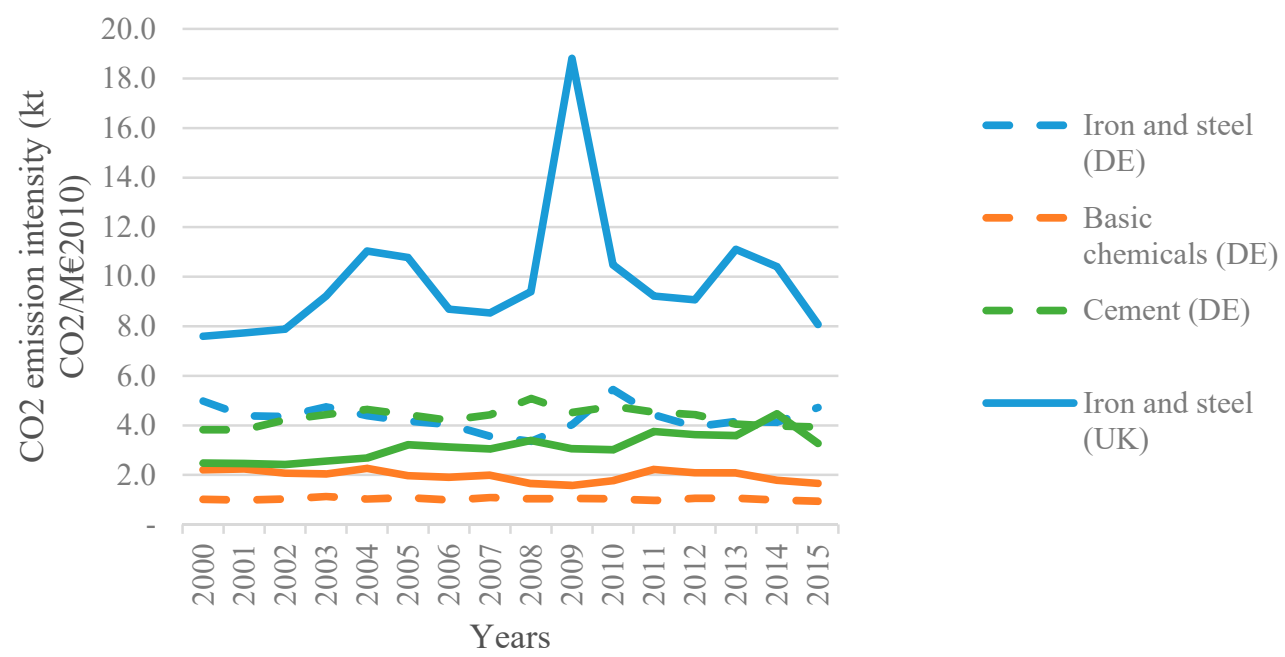

(b) $\mathrm{CO}_{2}$ intensity $\left(\mathrm{CO}_{2}\right.$ emissions per value added) per sector

Figure 4. Value added and $\mathrm{CO}_{2}$ intensity of energy-intensive industries in Germany (DE) and the UK (UK). Source: [35], own elaboration.

\section{Methodology}

The notion of innovation systems has been at the core of systemic analysis of dynamic interactions between actors, networks and processes to trigger technological change [36], as part of the evolutionary theories of economic and technological growth [37,38]. Technical, scientific, social, economic and political considerations influence innovation as a collective entity, leading to transformation through technological development [39]. Within literature, there have been a variety of different concepts of innovation systems developed, each focusing on different levels of analysis, like national (NIS) [40-42], regional (RIS) [43-45], sectoral (SIS) [19,20,46,47] and technological (TIS) [48] innovation systems-Asheim et al. [49] illustrate how the different innovation systems relate to one another, building on Frenz and Oughton [50]. Depending on their focus, these analyse innovation processes through different but increasingly blurred boundaries [51]. Although they are considered fundamentally international and multi-sectoral, Bergek et al. [52] suggested TIS can be used to examine the diffusion of technological innovation with both geographical and sectoral focus; Nikas et al. [53] integrated TIS with system maps, a framework to capture the different dynamics present in the systems of innovation, as an 
extension of "market maps" [54]. Markard and Truffer [55] discuss system boundary delineation to create an integrated framework establishing NIS-SIS-TIS interconnections, while also connecting them with the multi-level perspective (MLP) [56,57], an analytical approach to understanding sociotechnical transitions towards radical innovation. Similarly, Chung [58] built upon the idea of a unified National, Social and Technical Innovation System (NSTIS) of Taiwan's biotechnological sector.

The SIS, in particular, has been implemented in various case studies of different sectors and industries, like power generation [59], buildings [60], capital goods [61], natural resources [62], facilities management [63], photovoltaics [64], food [65] and housing [66]. Decarbonisation of energy-intensive industries has also received significant attention in literature. Lechtenböhmer et al. [67] examined electrification of basic materials production in the EU across multiple sectors, in an approach similar to Åhman et al.'s [68] study of Sweden's industrial transitions. Gerres et al. [3] examined decarbonisation at European level, mainly focusing on technologies like CCS. The first SIS application in decarbonisation of energy-intensive industries focused on the Dutch cement sector and the corresponding clean cement innovations [69]. Building upon this idea and the discussion on system boundaries, our study focuses on the SIS of the broader industrial sector in the national context of both the UK and Germany, despite the SIS generally not following national borders [46]. The fact that the SIS is applied to multiple industries and for two countries creates difficulties examining theoretical concepts in the context of the two systems. However, a detailed descriptive analysis is not pursued, rather than a mapping of the key structural elements. In fact, as we will observe in the analysis of the two SIS, the key industrial innovations of "green" hydrogen and CCS are in rather premature implementation phase in both countries. This indicates that the transition is still in early stages and no fundamental decarbonisation shifts have occurred, thereby avoiding the need to delve deeper into the systems, which is a key limitation of the SIS $[70,71]$. Therefore, a central point of our analysis lies in the examination of the technologies related to decarbonising the energy-intensive industries of iron and steel, cement, and chemicals from a macroscopic perspective, intending to find elements of each system that mostly affect diffusion of such innovations.

Our review is performed based on the four blocks identified by Malerba [19], which we briefly outline here (for a more detailed discussion of the SIS framework and its blocks, please see $[19,20,47,59])$ : "actors and networks", "institutions", "demand", and "knowledge, learning processes and technologies". Initially, the industrial primary and secondary actors in the two countries are mapped. However, the co-existence of these actors individually does not ensure effective diffusion of innovation [72]: it is through cooperation and established networks between the key players of an industry, public authorities and research institutions that innovation can be shared and cultivated [73]. Via institutional analysis, national policies affecting industry and setting a path towards decarbonisation are identified, along with similar European initiatives, like EU-ETS [74]. Demand also plays a key role in the market, not only as a consuming agent, but also in the adoption of new technologies and improvement of end products [75]. This is especially the case for industry, where the customer base comprises other large agents like the automotive industry [76,77]. Describing the existing knowledge base and the technologies currently dominating the industrial sectors, while explaining the opportunity conditions leading to emergence of innovative processes [78], the learning block plays a fundamental role in the innovation system: knowledge transfer allows to examine technological diffusion pathways in the system.

The UK and German SIS are then fed into a comparative analysis, where barriers to entry for the diffusion of decarbonisation technologies can be drawn from a systemic perspective, potentially leading to carbon lock-ins [79] and subsequently to failure to adapt to new technologies and policies [80], thus failing to meet emission targets. The analysis is performed based on the four types of innovation system failures [22]: institutional, infrastructural, capabilities and interactions. Introducing the system failures approach in the comparative analysis allows us to deviate from a strictly structural comparison of the individual case studies, thereby enhancing our perception of the ability of the two systems to manage innovation. It is often argued that identifying failures or barriers without applying a 
more process-oriented framework like the TIS is difficult [36,52]. However, low-carbon transitions are still in early stages, since technological innovation processes are almost non-existent, as showcased in our analysis, and the TIS, mostly used to investigate the evolution of a system as a technology evolves over time [52,81], has not yet emerged. Unlike in cases of better-established technologies (e.g., [82]), this therefore renders focus on technological processes to explicate the sectoral configuration difficult. To avoid these implications and better serve the objective of the study, we integrate the SIS with the system failures framework. The former is used to structurally analyse the systems from a macroscopic perspective, given the multiple subsectors and the two countries, while the latter helps identify potential bottlenecks in the envisaged transition and suggest policy interventions that elude these failures. The types of failures recognised in this framework are directly correlated with barriers extensively identified in literature on energy-intensive industries [7,83-87]. System failures generally relate to problems occurring in a given system [88], while barriers are obstacles that contribute to slow diffusion of innovation [89]. Addressing both system failures and barriers is key to designing effective policies that support innovation through all various stages [88,90]. Given the early stages of the transition, understanding possible failures that these barriers could lead to is critical in addressing them timely and mitigating their negative impact [91]. The connection of these types of failures with the SIS building blocks enables integration of the two theories in the conceptual framework presented in Figure 5, while the way in which the building blocks are put together is explained in the following paragraphs. Although the SIS and the system failures frameworks have only recently been applied for exploring the Norwegian and Canadian transport sectors [92], this is the first study to employ these frameworks with the aim to assess the industrial low-carbon transition potential, and the first to introduce the integration of the two frameworks in a structured and systematic approach.

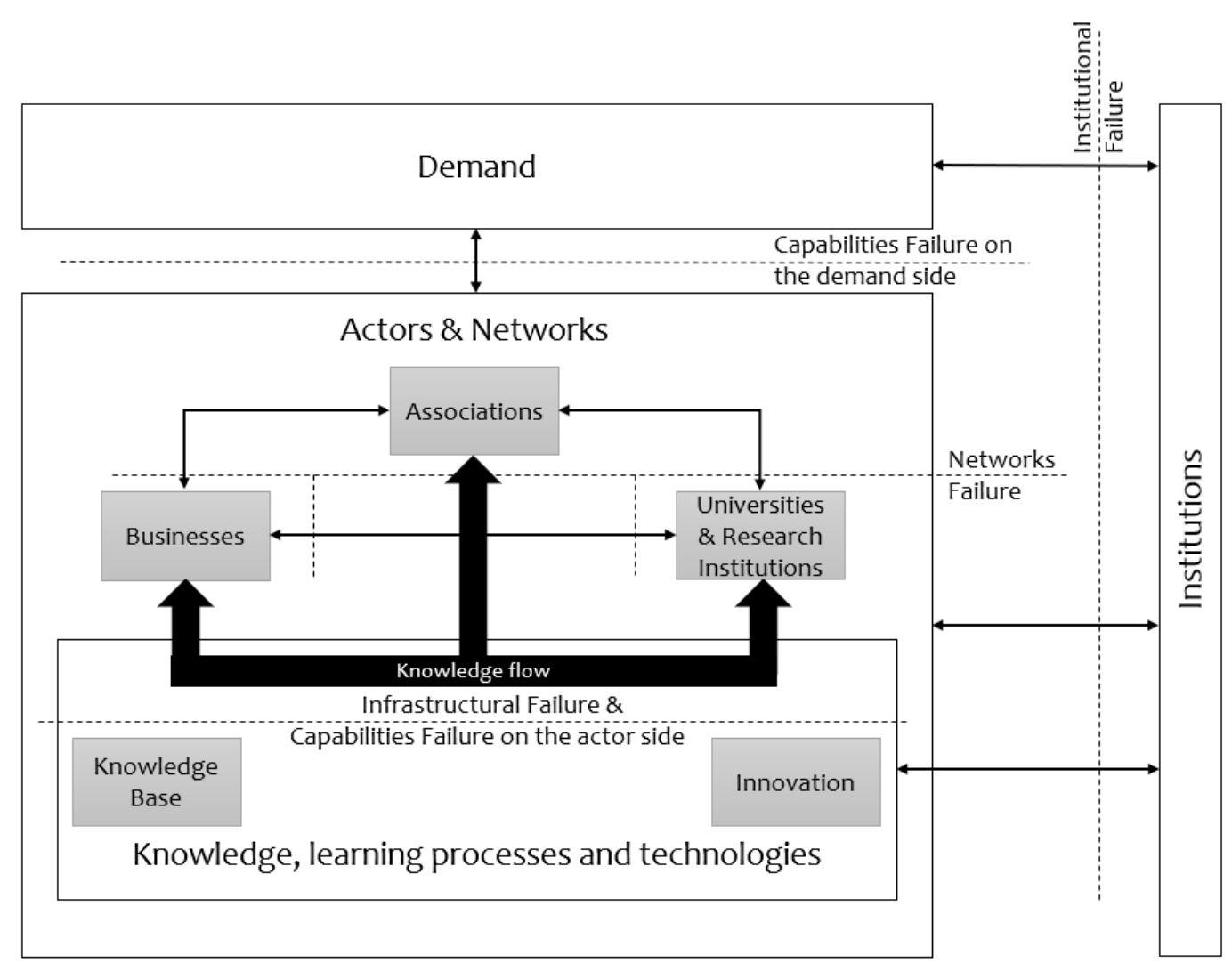

Figure 5. Theoretical approach for the integration of the SIS and the system failure framework.

Initially, a central element of any innovation system is the block of actors performing key sectoral activities, which are not only limited in the production of the goods examined but include research as well representational activities from associations. Communication networks established between 
the different system players are vital for the system's effective operation. From that perspective, the combination of this block with the interaction's failure is evident. These interactions can be divided into weak and strong [93]. Both negatively affect interactive processes of learning, which are vital in fostering innovation [94], either by weak exchanges among actors hindering innovation or by tight connections that can be inefficient to exploit opportunities [95], not allowing innovation to surface at all [96].

The institutional block operates on a broader level with policies affecting all aspects of the systems, including the main actors and the demand side, but also knowledge and innovation, especially through funding channels and strategies, evidently relating to potential institutional failures. These can be hard or soft [93]. The former is associated with the legal and policy framework, including health regulations and labour laws indirectly affecting the system, which are fundamentally similar with the institutional block of the SIS. The latter is mostly related to a wider spectrum of cultural standards, norms and habits in the society. For industrial sectors where citizens are not direct buyers of the goods produced and therefore have no consuming power, society can only demand policy change through pressure on institutions [97]. Therefore, in our case soft failures can be linked with institutions, although the linkage needs to be properly studied, especially when citizens act as consumers in the system.

The connection of demand with the system lies mainly in the purchasing process between buyers and producers. From that aspect, demand can be linked with the demand side of the capabilities failure, as established by Zhang and Liang [80]. This linkage is built on the willingness or ability (e.g., existence of sufficient resources) of buyers to purchase "greener" products that can be costlier than old products. The demand block is also affected by policy regulations (e.g., taxation).

Finally, the knowledge/learning block is presented as emerging from inside the actors' block, either through the main actors exploiting the existing knowledge base, or through development of innovation. Depending on the origin of innovation, since research is performed by both research institutions and businesses, knowledge flows to the rest of the actors' block. Knowledge can be linked with two types of failures: infrastructural failures, like ICT infrastructure, energy supply or testing facilities; and actor-side capabilities failures, related to actors' capacity to make the leap and adapt to new technologies.

Our main research question examined in this study orients on the ways in which the UK and German industrial sectors are formed from a sectoral systemic perspective and how decarbonisation technologies are diffused within and across the innovation system. Drawing from the structural properties of the systems, specific barriers that may act as bottlenecks in the diffusion of innovation are also identified, potentially leading to system failures in coping with sustainability transitions. These outputs are then translated into policy implications.

\section{The German Industrial SIS}

Industrial Revolution in Germany began in the mid-19th century. State governments rapidly developed a rail system to minimise distances in the country, lowering costs of regional trade, making it feasible to serve distant markets from central locations, and providing incentives for manufacturers to concentrate production in central areas and around coalfields. In the Ruhr Valley, fully developed coalfields helped Germany become the foremost coal producer in Europe. Concentration of accessible coal deposits in central Germany explains the higher rates of industrial employment in coal-rich regions, compared to German regions that lost traditional manufacturing centres [98]. A steel industry emerged, and the stimulus of coal and steel development expanded the banking and capital markets available nationwide, triggering growth of other industries like the chemical and electrical sectors in the latter part of the 19th century, with German chemical industry becoming the most advanced globally. Coal-using technologies invented over the course of the 18th century progressively improved and were increasingly adopted during the following centuries [99]. 


\subsection{Actors and Networks}

German industry comprises an advanced network of interconnected actors where knowledge and innovation diffuse. On a macro-level and with a quarter of the country's GDP deriving from industrial products, the Federation of German Industries (BDI) and the Energy-Intensive Industries in Germany constitute networks of industry associations representing interests of various sectors in political decision-making, showcasing industry's impact on society. Research-wise, the German Association of Technical and Scientific Societies provides policy recommendations towards scientific progress on technical issues from thousands of organisations in their network. Financially, Germany Trade \& Invest connects domestic businesses with the global market to trigger investments, also helping foreign enterprises set up in Germany.

These activities are supported by the Federal Ministry for Economic Affairs and Energy (BMWi), the leading authority on industrial policy regulation and a key player in financing R\&D activities. This is vital for sub-sectors like chemicals that mainly comprise small and medium enterprises (SMEs) relying on public investment and tax reductions to finance R\&D operations. BMWi also supports universities and non-academic research organisations.

Regarding iron and steel, the German Steel Federation (WV Stahl) is a significant political influencer affecting both the national steel industry and global market. It focuses on creating an effective political-economic environment for German steel enterprises to be competitive, assisting numerous autonomous institutes like the VDEh Steel Institute, the VDEh Institute for Applied Research, the Research Association for Steel Application and the Information Center Stainless Steel, to promote innovation and perform applied research. An interesting public-private collaboration is the Max-Planck-Institut für Eisenforschung, an autonomous research institute, equally financed by VDEh and the Max Planck Society for the Advancement of Science, ensuring research results are useful scientifically and market-wise.

Manufacturing companies play an important role in maintaining iron and steel production, with local and global operations and exports being a key activity. However, large multinational companies foster competitive instabilities in the system, like price-fixing [100]. The private sector also contributes to the iron and steel sub-system from an innovation perspective; indicatively, Siemens VAI was the leading research body to establish the COREX and FINEX ironmaking processes [101].

The cement industry is more diversely structured, compared to steel: contrary to most manufacturing operations coming from key steel players, cement is produced by both large- and medium-sized companies. Institutionally, a key actor is the German Cement Works Association (VDZ) representing interests of cement companies producing multi-billion-euro sales. Like WV Stahl, VDZ operates a network of organisations, representing German cement manufacturers and promoting diffusion of knowledge, technology and research in production and environmental management. These activities are further elaborated from the Research Institute and Environmental Measuring Body for effective monitoring of production plants, which is independent from VDZ ensuring research credibility. PÜZ and FIZ-Zert are responsible for product certification according to standards and emissions respectively.

The German chemical industry has a completely different structure due to the vast plethora of goods produced. A key characteristic is the high share of SMEs, representing $90 \%$ of total workforce, which take advantage of increased innovation needs to formulate research-driven business models [102]. The German Chemical Industry Association (VCI) is the main association in chemicals representing over 1700 companies, organised in thirty sector groups and associations depending on area of operation [103], further proving the sector's structural complexity. Said diversity leads to difficulties in establishing chemistry-specific research organisations: apart from SMEs and large companies, most of the sector's research is powered by institutes like Max Planck Society, Fraunhofer-Gesellschaft, Helmholtz Association, and the Leibniz Association. 


\subsection{Institutions}

On a policy level, Germany must maintain the role of a major industrial nation, while implementing effective climate mitigation actions. This dual challenge is further reflected in the efforts of industrial lobbying associations to block regulatory interventions and reforms, or downgrade policies to voluntary actions [104]. Such efforts are further boosted by the industrial mentality of German society [105], as local influence may oppose initiatives affecting industry's regional added value, leading to more conservative approaches that do not threaten their interests [69].

Germany introduced a first version of feed-in tariffs in 1991, with the Electricity Feed-In Law obliging utilities to buy energy from renewable energy sources (RES) on premium prices, ensuring grid access to RES-based energy [106]. RES generation was also encouraged through the Renewable Energy Act [107], introduced in 2000 and revised in 2014 and 2017, setting a target for RES production of at least $80 \%$ by 2050 . As part of a strategy, the Energy Concept (Energiekonzept) was introduced in 2010 setting the target of 80-95\% GHG emissions reduction by 2050, while the Energy Transition (Energiewende) aimed at nuclear phaseout and further cut on fossil fuels [108].

In 1964, the German air pollution control regulation had been legislated as technical instructions of air quality control (TA Luft), setting the first limits regarding air quality standards, while in 1974 the Federal Immission Control Act set out general principles on harmful environmental practices [109]. TA Luft has since been revised oftentimes, setting stricter limits for air pollutants, leading to its 2014 revision that incorporated the Industrial Emissions Directive (IED) into national legislation [110], which aimed to oblige installations to operate according to BAT, creating legally binding conclusions that define new emission limits [111]. This was critical for Germany, since almost 10,000 of the total 45,000 permits issued under the IPPC Directive—a previous version of IED—regarded German installations [112].

Combined with IED, energy-intensive installations are bound to fulfil emission targets according to the EU-ETS and acquire tradable allowances to cover emissions [59]. EU-ETS implementation poses dangers for industry: cement and iron and steel are vulnerable since $60 \%$ and $25 \%$ of their gross value added (GVA) respectively could be at stake [113]. To protect them, the EU-ETS included a progressive transition to auctioning, through free allowances, meant to steadily decrease until 2020, when most would have been auctioned; however, to prevent emergence of carbon leakage [114], free allowances were continued with decreased proportion [115]. For German installations, this means that significant adjustments must be made to adapt to the increasing emissions they need to acquire.

These changes led to increased costs for system actors and must be considered, since major companies have already expressed interest in implementing actions for emission cuts requesting policy support but are reluctant due to lack of viable business plans [116]. In 2019, BMWi published a draft of the National Industry Strategy 2030, aiming to strengthen industrial competitiveness in Germany, while promoting innovation. However, this is still in open discussion, mainly due to strong criticism received over overestimations and introduced centralisation $[117,118]$. This indicates that on a policy level the transition is still in the design process.

\subsection{Demand}

In 2019, German industry experienced signs of recession reflected in lower production volumes [119]. Major challenges faced by the automotive industry [120] were partially responsible for the observed downturn [121] with its importance reflected in both the final output and the individual products consumed for car-making. This outlines two major effects that demand has on industry: a direct impact in terms of growth, in absolute numbers; and an indirect influence that consumers' preferences could have in knowledge and innovation diffusion [122]. Figure 6 illustrates the diverse sectoral shares of steel consumption in Germany, which remain historically steady [123] with construction, mechanical engineering and road vehicles being important consumers. 


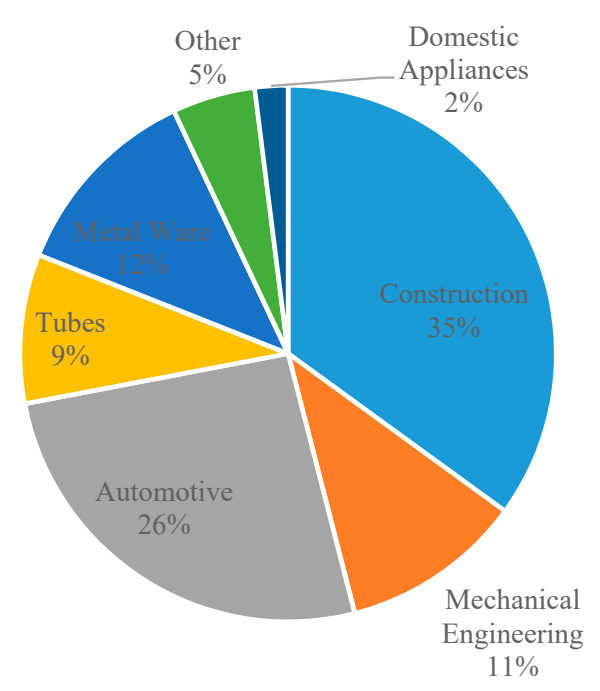

Figure 6. Sector shares of steel consumption in Germany in 2017. Source: [124], own elaboration.

German iron and steel industry produce tens of million tonnes of crude steel, with 13.3 of those being exported in 2017 to top steel markets like France and Poland [125]. Germany is also among world's top five wind markets [126]; steel demand for wind turbine manufacturing could therefore lead to green energy production over a turbine's lifetime, surpassing the energy required for steelmaking.

As with iron and steel, cement industry is also largely affected by the nature of end-consumers. At least $30 \%$ of total cement consumption is driven by the construction sector [127]. Consumption is relatively small compared to a total production of over 30 million tonnes [128], leading to significant exports alleviating risks through geographic diversification.

Chemicals, with a 2018 turnover of around $€ 200$ billion, is another industry heavily dependent on exports, which surpassed $€ 90$ billion that year, with Germany registering the highest trade surplus among European member-states [129]. It also plays the role of a facilitator for other industries, since $90 \%$ of chemical products are inputs into multiple industrial procedures [130]. Consequently, challenges of the automotive industry naturally affected the chemical sector, experiencing signs of crisis despite the boost of pharmaceuticals [131,132].

Decarbonisation policies affect not only these sectors, but their consumers as well, with problems in demand being transferred as sectoral challenges, as is also evident by the generalised effects of the financial crisis of 2008 in terms of energy consumption, emissions and emission intensity reflected in Figures 1, 2 and 4. Especially for German industry, where the automotive sector is significant driver of economic progress [133], consumers' technological needs have the potential to steer research and innovation towards more efficient techniques.

\subsection{Knowledge, Learning Processes and Technologies}

Industrial technological regime comprises different knowledge bases for individual sub-sectors, although iron and steel, cement and chemicals are commonly regarded as energy-intensive industries [134-136], with industrial energy efficiency and new practices receiving increasing attention on a policy and research level [137].

Traditional production routes dominate steelmaking in Germany. BF-BOF is responsible for almost $70 \%$ of total production, with the remainder mostly being produced by EAF and to a smaller extent from a single DRI plant [138]. Between 1991 and 2007, steel progressively increased EAF shares, leading to energy consumption decline [139] and the relatively low $\mathrm{CO}_{2}$ intensity of German iron and steel.

Accounting for $2.9 \%$ of Germany's GHG emissions [140], cement production processes play a key role in industrial energy consumption. After reunification, progress has been made in efficiency through significant reduction of the clinker ratio (to 73\% in 2011) [128]. Usón et al. [141] similarly 
observed substitution of fossil fuels by alternative fuels, like meat and bone animal meal, sewage sludge and biomass, to almost $60 \%$.

In chemicals, dominant processes greatly vary, due to diversification of final products. Chemicals account for $19 \%$ of total industrial energy consumption, which is mostly attributed to ethylene, chlorine, carbon black, ammonia, methanol, and polymers [142]. Ammonia synthesis is still based on the 1908 Haber-Bosch process [143], and despite being considered energy-intensive [144] the final product's agricultural usefulness [145] outweighs negative effects. Similarly, ethylene production from cracking naphtha, the basic material used in Germany, is also considered energy-intensive [146].

Evidently, German industry borders are relatively strict, given endurance of certain processes as dominant production drivers through time. Therefore, structural adjustments must be made for the sector to cope with increased necessity for industrial decarbonisation [67]. In fact, most installations already tried to deal with the environmental impact of their operations, by applying BAT $[111,147,148]$. However, further BAT-compliant improvements are subject to limitations regarding long-term targets $[134,138]$. Shift to less $\mathrm{CO}_{2}$-intensive production was attempted when ArcelorMittal opened the first DRI plant in Hamburg. The DRI process could create high-quality iron to be used in EAF due to increasing need for scrap [149]. However, DRI being expensive [138] limited further diffusion. As a result, reaching the ambitious targets of the German policy requires breakthrough innovations, strategically crossing the boundaries of individual sub-sectors [150], while maintaining financial viability.

One promising technology is CCS: industrial installations in Germany are forming localised clusters, which are ideal for implementing CCS [151] to reduce $\mathrm{CO}_{2}$ emission in the examined sub-sectors [152]. Domestic CCS projects are still at pilot implementations, gaining mixed reactions from society due to perceived risks of living nearby storage sites [153]. Lack of public acceptance has forced many projects to be cancelled or put on hold, causing financial, political and legal issues [154]. Public misconceptions also exist in the use of alternative sources for chemical production [155]. Since public acceptance is a major driver of change, such projects should also focus on cultivating positive public perception.

Another promising technology is low-carbon hydrogen electrolysed from RES, i.e., green hydrogen. This could benefit iron and steel, as hydrogen can be used as a reduction agent to directly reduce iron ore, but also for hydrogen-based ammonia production [156]. Private companies appear interested in diffusion of hydrogen-based technologies. Salzgitter launched the Green Industrial Hydrogen project in 2016, aiming to develop a high-temperature electrolyser $[157,158]$. ArcelorMittal has also been working on an experimental hydrogen project at Hamburg's DRI plant, to further reduce its emissions. These examples show industry is keen on hydrogen to deeply cut emissions, with multiple German stakeholders requesting a hydrogen strategy from the government, combined with efforts towards a "European Hydrogen Strategy" [159].

Encouragement for renewable energy production in Germany provides a great opportunity for "green" hydrogen to emerge, while exploitation of DRI plants indicates a certain degree of cumulativeness, despite the generally well-established knowledge base. Similarly, local clusters provide an area for installing CCS, which can be combined with the existing dominant processes. Research is also accessible to firms even from external sources, like research institutes. These technologies show great potential in the key dimensions of knowledge [47], even though, on aggregate, the "opportunity" for the industrial regime is not provided through powerful incentives, but rather fear of increased costs from $\mathrm{CO}_{2}$ emissions.

\section{The UK Industrial SIS}

Between 1770 and 1850, the UK was the first country to undergo industrial revolution, of which the most important component was iron and steel production. Despite significant lack of scientific knowledge, the revolution was achieved by means of empirical methods. Several successful innovators developed spectacular patents for steel production, even though they had no industrial 
background [160]. Industrial innovations also increased as the UK was endowed with extensive cheap coal supplies, providing cheap energy and lucrative export trade. Innovations and cheap coal supplies led to rapid development of engineering, railways, construction, shipbuilding, etc. Historically, during the 1600s, England's iron production was around 20,000 tons/year, a value that did not vary much until after 1750, with the Shropshire coalfield being an iron-making centre since the 16th century. In 1767, the first iron rails were used and, in 1781, the first cast iron bridge was built. Rapid growth was a stimulus for implementation of new industrial methods, such as use of coke in reverberatory furnace to forge wrought iron [161].

\subsection{Actors and Networks}

Energy-intensive industries are also capital-intensive, considering construction costs of manufacturing plants; therefore, they are generally characterised by few incumbent multi-national firms and several midstream enterprises that process iron, steel and cement to produce components for a diverse variety of industrial applications. Prices of raw materials used by midstream firms are therefore considerably affected by the few upstream companies [162]. Nevertheless, the latter are also dependent on midstream firms, as these account for a significant fraction of their sales. The structure of the iron and steel industry has undergone significant restructuring, from the 1988 privatisation [163] to mergers and acquisitions throughout the 2000s [164]. The same applies in chemicals, where global reshaping led to establishment of companies resulting from mergers [165], although the sector includes numerous SMEs [166], due to the broad spectrum of products.

A prominent industry association, operating both inside and outside UK borders, is the Confederation of British Industry (CBI), counting members employing almost one-third of private sector workforce. Its main purposes include promotion of UK business interests by applying pressure to the government, network creation, policy analysis, and knowledge transfer. MAKE UK is a federation consisting of various manufacturing and technology firms, including producers of iron and steel products, with a main purpose of providing advice and expertise on climate, environment and employment. A similar trade association providing advice to industrial actors is the Mineral Products Association, consisting of businesses operating on or producing cement among others. Finally, the Chemical Industries Association represents energy-intensive firms producing chemical and pharmaceutical goods.

The UK hosts some of the most highly ranked universities in the world, including Cambridge, Oxford, and Imperial College London. The latter has established the Corporate Partnership Programme and Industry Partnership and Commercialisation, aiming to bring students and companies closer, in terms of employment and new industrial technologies. One-third of the budget for the tailored to industrial problems engineering research programme of the University of Cambridge comes from collaborations with industrial corporations. The University of Oxford provides consulting services to various industries, and via forming spin-out companies, facilitates capitalisation of university research on real-world applications. The country is therefore a pioneer in technological research, having produced $14 \%$ of the most highly cited publications [167], which is closely linked to industry attracting significant investments in research [168]. University-Industry cross researchers with combined affiliations [169] and co-authored publications reflect productive research cooperation between industrial firms and universities. Apart from research carried out in universities, the government funds multiple research programs and initiatives, such as the Industrial Strategy Challenge Fund, as part of the government's Industrial Strategy aiming to increase productivity and contribute to decarbonisation.

The Department for Business, Energy and Industrial Strategy (BEIS) plays a significant role in formulating industrial transition pathways, aiming to ensure a low-cost, clean UK energy system. Responsibilities of the Ministry of State for Universities, Science, Research and Innovation include reform of university education, science and research, innovation and technology; jointly administered by the Department for Education and BEIS, the ministry can stimulate universities to further engage on environmental research applied in industry. Finally, the Department for Environment, Food and 
Rural Affairs also targets sustainable development, which is directly connected with use of cleaner, less energy-intensive technologies.

Finally, the Committee on Climate Change, a non-governmental public organisation, aims to advise the government towards achieving GHG cuts and adapting to climate change, like the government's targets of net-zero emissions. The committee assesses and reports progress of the country's transition to a cleaner economy and helps the government introduce Industrial Decarbonisation and Energy Efficiency Roadmaps.

\subsection{Institutions}

The UK was an EU member-state until 31 January 2020. Environmental legislation includes national and European (commonly shared with Germany), with obligations towards the latter being subject to negotiations in progress.

In 2008, the country legislated an integrated environmental permitting regime, in which industrial enterprises must obtain an environmental permit to operate. These permits refer to industries producing heavy land, water and air emissions; mild such emissions; or only air emissions. Industrial plants are obliged to remain within the permit's emission limits and upgrade production plans accordingly to remain operational. The revised Climate Act was legislated in 2019, making UK one of the first countries set to achieve net-zero emissions by 2050, with implications for all three sectors.

The UK was obliged to implement European legislation across various aspects. Critically, EU environmental policies focusing on climate change include the IED and BAT limits for each industrial sector [170] and the EU-ETS setting increasingly stricter limits for companies and industries to reduce carbon footprint. Existent EU legislation will remain in force until the end of 2020, allowing the UK to achieve smooth transition towards complete legislative and authoritative autonomy. After 2020, the UK government will be free to form their own environmental policies; upon decision to remain in the European Economic Area, it will still be able to participate in the EU-ETS.

\subsection{Demand}

Industry has been the country's powerhouse during the last two-and-a-half centuries. Home of the first industrial revolution, in which machines were first introduced and used, and which boosted UK economy and real wages [171] and was the cornerstone of rapid development of many other sectors like engineering, shipbuilding and railways [160], the UK became one of the largest economies worldwide until today.

Iron and steel are used in various applications and industries. The largest amounts are used in construction, followed by manufacturing, including vehicles and mechanical equipment. In the last 25 years, although national GDP steadily increases, manufacturing GDP has shown negligible change, in contrast to services that have doubled their GDP in the same period [172]. This indicates that the UK economic model is shifting towards an era promoting production of services over goods, as seen in Section 2, which may in turn result in reduction of iron and steel demand and production.

Cement is widely used in the building sector for manufacturing beams, floors, wall blocks, and so on. It can also be used for construction of infrastructure, like bridges, tunnels and railways [173]. Contrary to manufacturing, the construction sector's GDP has risen by almost 20\% since 1990 [172]. Nevertheless, in the same period, production of cement in the UK has dropped by $50 \%$ [30], and increasing demand is met by imports.

Chemicals and pharmaceuticals constitute the second largest UK industry. Most common products include plastics and polymers, like polycarbonate and polyethylene [174], with renowned firms established in the UK, including some of the most profitable pharma industries. Contrary to iron, steel and concrete, production of chemicals has remained steady during the last twenty years, whereas its GVA has increased by almost $40 \%$ since 1996, showing competitiveness, despite cheaper products from countries like China because of lower wages and production costs. A quarter of total production is directly supplied to households, which may hesitate to try unfamiliar brands. 
Since the early 1990s, global economy has entered a new era; US, EU and Japanese industrial dominance has started losing grip, with several industrial powerhouses emerging, including Mexico, Indonesia, India and China. Particularly, China has quickly become one of the biggest economies in the world, mainly because of its rapid industrial development; its iron, steel and cement production has increased twenty-fold and cater more than $50 \%$ of worldwide demand [175]. The UK, among other countries, has started depending on imports from China or other emerging countries rather than their own industry; and domestic production has been facing significant downfall, apart from chemicals that remained steady, while manufacturing GDP also remained steady despite increase in national GDP, indicating that GDP growth from production has not occurred in the UK, especially considering pressures from the 2008 financial crisis that further limited energy consumption and significantly increased emission intensity (Figures 1 and 4).

\subsection{Knowledge, Learning Processes and Technologies}

$\mathrm{BF}$ is the dominant technology in iron and steel, with coal accounting for $70 \%$ of total energy required; EAF accounts only for $2.5 \%$ of total sectoral energy demand [176], as also reflected in only $17 \%$ share of total production [177], due to difficulties in importing scrap [178]. This makes it the most polluting industrial sub-sector, accounting for $25 \%$ of its industrial GHG emissions [179]. The lower share of EAF is also a key factor for UK $\mathrm{CO}_{2}$ intensity being higher than Germany's.

The technological setting for cement production is similar, with two types of processes: heating of raw materials (limestone); and electricity use to transform already produced or used cement. The UK has been among pioneers in alternative fuels: in 2014, the energy mix of this process comprised $60 \%$ coal $/$ petcoke, $18 \%$ biomass and $22 \%$ non-biomass waste [180]. These emitting processes account for $8 \%$ of UK industrial emissions [179].

In contrast, chemicals are characterised by an extended number of thermal or chemical processes fundamental to producing plastics, like polymerisation and steam cracking. Different fuels are used, such as naphtha, oil gas, butane, etc. [12], making the sector a major pollutant, accounting for $19 \%$ of UK industrial total GHG emissions [179].

Numerous low-carbon techniques and technologies exist that can replace the dominant processes. Some can be applied to specific sub-sectors and others feature a broader scope of applications. The latter may have much greater impact on emissions abatement, especially if adopted in the entire industry. UK's roadmap to industrial decarbonisation until 2050 [181] identified cross-sectoral technologies; for all three sectors, the most important are BAT, fuel switching (like hydrogen or biomass), CCS and energy efficiency.

BAT-compliant modification of industrial plants, encouraged by EU legislation, is a first step towards greener industry, contributing to energy efficiency and reducing production of various air pollutants [182]: in iron and steel, adaptation to BAT can result in reducing energy consumption by 1GJ per tonne of steel [183]. A common BAT application is heat recovery in several stages of iron and steel production, such as BF and sintering [176].

Achieving a net-zero emission industry also entails adoption of cutting-edge technologies, like CCS. For cement, calcination accounts for $60 \%$ of all GHG emissions, with the remaining $40 \%$ being caused by fossil fuel combustion [184]. The former emits $\mathrm{CO}_{2}$ regardless of the heating fuel used, which provides the necessary opportunity for CCS to be implemented; as such, CCS is critical for the 2050 target and, as a relatively new technology, requires more research, with universities and research institutes to play an important role in order to increase research accessibility.

Another promising solution in iron and steel lies in low-carbon hydrogen since combustion produces little-to-no $\mathrm{CO}_{2}$ emissions. The UK is an important stakeholder in hydrogen research and production; most of its hydrogen plants use steam methane reforming (SMR) [185], resulting in $\mathrm{CO}_{2}$ emissions [186]. Hydrogen use for emissions-free industry requires promotion of green hydrogen plants and use of CCS in SMR installations. The supplementary nature of the two technologies in the 
UK provides an opportunity that builds on cumulative knowledge allowing further diffusion of both in the transition.

\section{Comparative Analysis Based on the System Failures Framework}

Industry has globally locked-into extensive fossil fuel use, driven by dominance of well-established energy-intensive processes [187] acting as barriers to implementing green technologies [188]. Such barriers disrupt innovation diffusion and delay adoption of carbon-neutral techniques and transition towards sustainability [189]. Here, we study the ability of these barriers to cause system failures for Germany and the UK, by examining SIS features. A visual representation of the SIS for the two countries along with the corresponding failures is provided in Figure 7. A discussion of the findings reflected and illustrated in Figure 7 is included in Table 1, which summarises resilience factors and potential causes of failures faced by each sector.

Table 1. Resilience factors and potential causes of failures in the German and UK industrial systems.

\begin{tabular}{|c|c|c|c|c|}
\hline & \multicolumn{2}{|c|}{ Germany } & \multicolumn{2}{|r|}{ UK } \\
\hline & $\begin{array}{l}\text { Resilience to } \\
\text { Failures }\end{array}$ & $\begin{array}{c}\text { Potential Causes of } \\
\text { Failures }\end{array}$ & $\begin{array}{l}\text { Resilience to } \\
\text { Failures }\end{array}$ & $\begin{array}{c}\text { Potential Causes of } \\
\text { Failures }\end{array}$ \\
\hline Interactions & $\begin{array}{l}\text { Network of active } \\
\text { associations and } \\
\text { companies } \\
\text { A large number of } \\
\text { SMEs especially for } \\
\text { the chemical sector }\end{array}$ & $\begin{array}{l}\text { Strong network } \\
\text { interactions lead to } \\
\text { lobbying practices and } \\
\text { strategic decisions that } \\
\text { threaten competition }\end{array}$ & $\begin{array}{l}\text { Renowned } \\
\text { universities that } \\
\text { perform research } \\
\text { activities } \\
\text { A large number of } \\
\text { SMEs especially for } \\
\text { the chemical sector }\end{array}$ & \\
\hline Institutional & $\begin{array}{c}\text { Active } \\
\text { environmental } \\
\text { policy } \\
\text { Optimistic targets } \\
\text { and political will to } \\
\text { achieve them }\end{array}$ & $\begin{array}{l}\text { Industrial strategy } \\
\text { hesitant and } \\
\text { overoptimistic } \\
\text { Industrial Policy not } \\
\text { elaborated regarding } \\
\text { high cost innovation } \\
\text { Strict regulation causes } \\
\text { fear of carbon leakage }\end{array}$ & $\begin{array}{c}\text { Active } \\
\text { environmental } \\
\text { policy } \\
\text { Optimistic targets } \\
\text { and political will to } \\
\text { achieve them }\end{array}$ & $\begin{array}{l}\text { Industrial Policy focuses } \\
\text { more on financial rather } \\
\text { than environmental issues } \\
\text { Limited funding for a vast } \\
\text { number of policies } \\
\text { Strict regulation cause fear } \\
\text { of carbon leakage } \\
\text { Uncertainty after } \\
\text { withdrawing from the EU }\end{array}$ \\
\hline Capabilities & $\begin{array}{l}\text { Strong consumers } \\
\text { (e.g., automotive } \\
\text { industry for the } \\
\text { iron and steel } \\
\text { sector) } \\
\text { Adequate } \\
\text { operational } \\
\text { capabilities } \\
\text { High share of EAF } \\
\text { compared to } \\
\text { BF/BOF for steel } \\
\text { production } \\
\text { Existing DRI plant }\end{array}$ & $\begin{array}{l}\text { Possible downturn when } \\
\text { the automotive industry } \\
\text { faces problems } \\
\text { Problem supporting } \\
\text { innovative processes due } \\
\text { to high investment cost } \\
\text { Consumers reluctant } \\
\text { over higher cost of } \\
\text { "green" products } \\
\text { Carbon lock-into } \\
\text { conservative dominant } \\
\text { processes } \\
\text { Difficulty in combining } \\
\text { technologies like CCS, } \\
\text { EAF }\end{array}$ & $\begin{array}{l}\text { Adequate } \\
\text { operational } \\
\text { capabilities }\end{array}$ & $\begin{array}{l}\text { Problem supporting } \\
\text { innovative processes due to } \\
\text { high investment cost } \\
\text { The shrinking industry } \\
\text { causes decline in demand } \\
\text { Consumers reluctant over } \\
\text { higher cost of "green" } \\
\text { products } \\
\text { Carbon lock-into } \\
\text { conservative dominant } \\
\text { processes } \\
\text { Difficulty in combining } \\
\text { technologies like CCS, EAF } \\
\text { Low share of EAF } \\
\text { compared to BF/BOF for } \\
\text { steel production }\end{array}$ \\
\hline Infrastructural & $\begin{array}{c}\text { Strong } \\
\text { Infrastructures }\end{array}$ & & $\begin{array}{c}\text { Strong } \\
\text { Infrastructures }\end{array}$ & \\
\hline
\end{tabular}




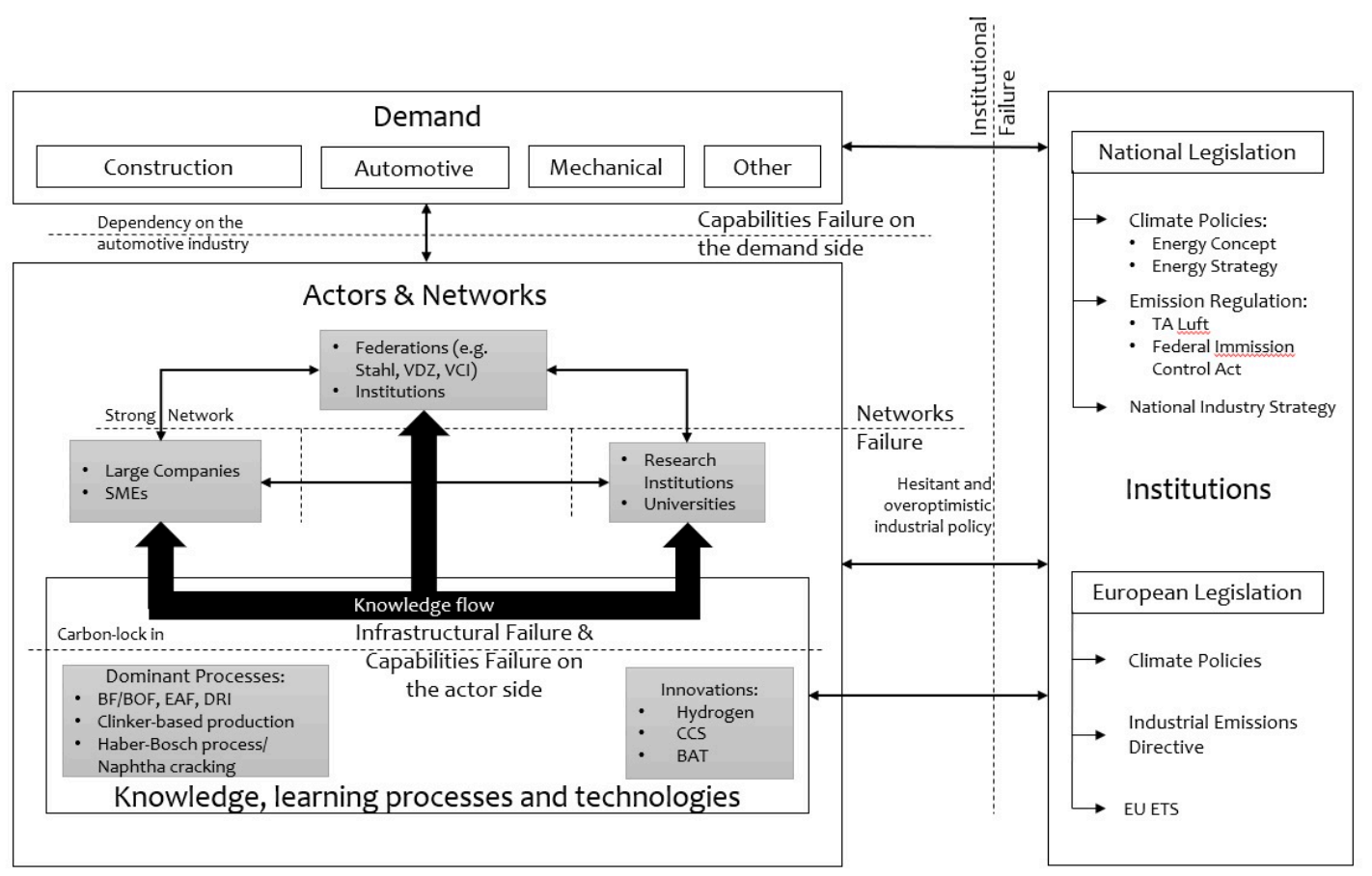

(a) Germany

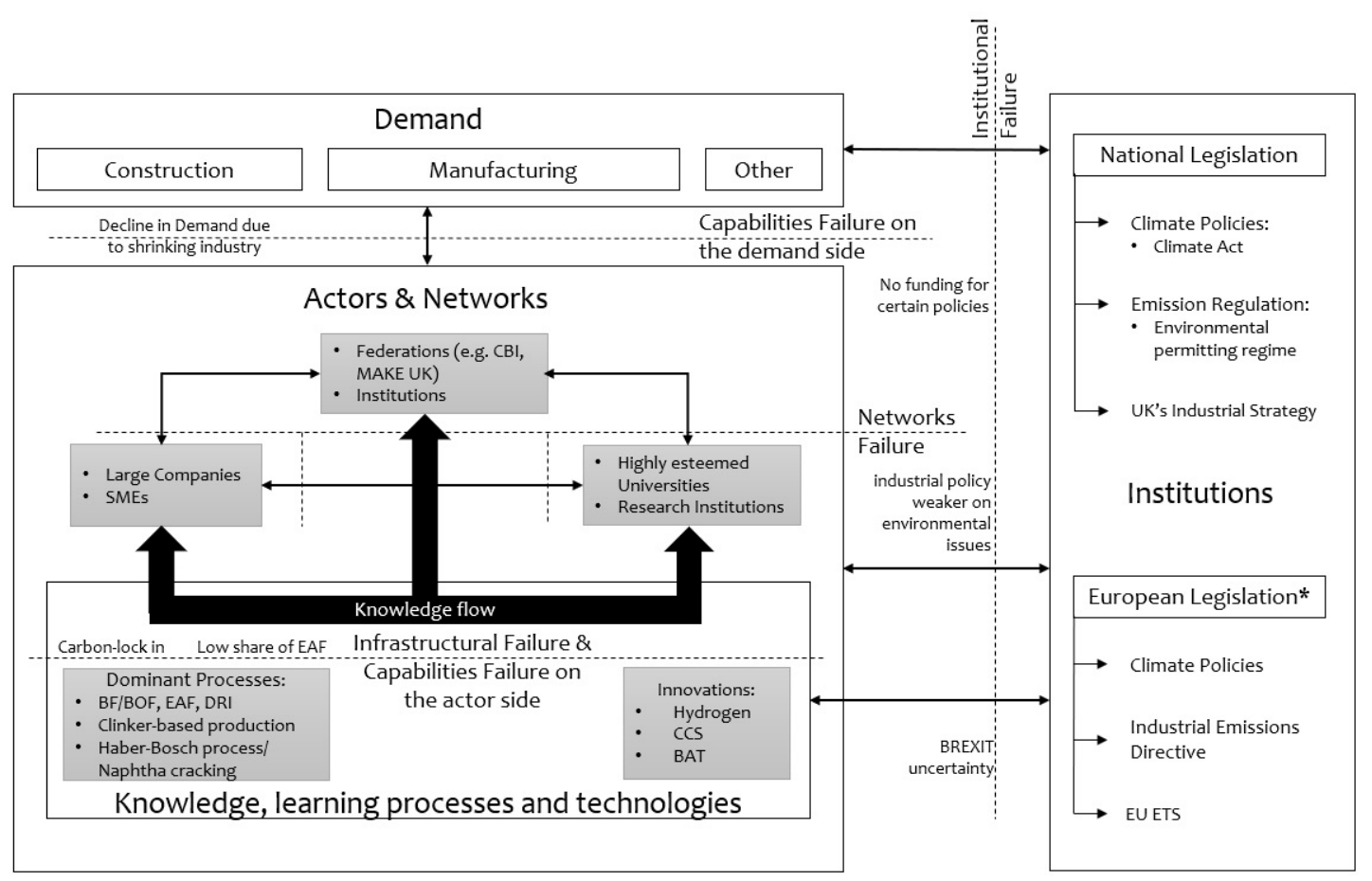

(b) UK

Figure 7. Industrial SIS for (a) Germany and (b) UK with the main potential causes of failures observed.

\subsection{Interactions}

The network structure of both industrial innovation systems appears similar. The three sub-sectors consist of active firms in both countries, research and academic institutions, government entities and business confederations. Nevertheless, internal relations and balances between agents vary significantly. German iron and steel industry feature a larger, more influential network of firms and associations, with some of the largest stakeholders located or headquartered in Germany, with 
implications for the global iron and steel market. The shrinking UK sector is characterised by fewer stakeholders. A similar phenomenon is observed in their cement industries. In contrast, both chemical sub-sectors host and affect critical stakeholders, with ties especially to pharmaceuticals.

Germany is considered more influential regarding firm operation and relevant corporate associations. However, these interactions show characteristics of powerful networks, with incidents of price-fixing and lobbying. Such networks, forming a compact regime, can block innovation if collective interests are threatened, leading to interaction failures. The UK features a more interactive research pillar, with renowned universities involved in industrial R\&D.

The two countries show significant resemblance in governmental entities' interactions with the system. The most relevant UK governmental entity is BEIS; in Germany, jurisdiction lies upon the Ministry for Economic Affairs and Energy. Both interact similarly with industry, through environmental policies or strategies aiming to help companies carry out technological R\&D.

Industrial networks differ in the two countries but are generally stable in the interactions developed: they are well-constructed and have numerous incumbents, with Germany focusing more on associations and UK on universities and research institutions, which makes it easier for the latter to establish effective networks without significant barriers. System failures caused by agents' interactions is not highly possible in either country, although actors' strategic practices can threaten competition, if no regulations take place. To overcome resistance to innovation and change, especially in Germany, it is imperative to design specific policies that pose stricter emission targets, or border taxes, while providing industry-specific support to assist innovative activities.

\subsection{Institutions}

The UK experiences a long-lasting transition from manufacturing towards services, altering societal structure in the form of shifting employment balances and leading to shrinking industry. Sectoral inability to keep up with overall economic growth leads to decreased investments within the sector [190] and to decreased chances of developing technological innovation. Given the high correlation between investment in research and productivity [191], transition towards services is a key challenge for UK industry, since it is more susceptible to decreased investments, potentially leading to severe institutional failures, unless adequately addressed. Existing companies in a shrinking environment are more vulnerable to locking-into traditional, carbon-intensive operations to secure profits [192]. An observed global societal transition towards services as a substitution of industrial manufacturing [193] indicates that adjustments are necessary even for the more stable German industry.

Policy-related routes have also been crucial for the success or failure of big firms and industries [194,195]. Both countries have demonstrated legislative determination towards climate change mitigation, having equally legislated their National Energy and Climate Plans, formulating decarbonisation strategies with industrial emission targets. With EU legislation active also in the UK until the end of 2020 despite Brexit, both have also adopted environmental legislation, directives and regulatory mechanisms, like the EU-ETS, IED and BAT. However, specific industry-related strategies in both countries lack novelty, with UK strategy focusing more on financial rather than environmental issues [196], while also receiving criticism over limited funding on some policies [197]. The German draft also received significant criticism. The observed policy inconsistency is attributed to leniency of industrial emission targets to avoid carbon leakage to other countries with more permissive emission legislations. These include countries without ETS schemes, or countries with heavy and competitive industries and an established nation-wide ETS, like China, which however feature significant shortcomings like low market activity, single-mode settings, lack of national-level legislation, and limited data transparency [198]. Harmonisation of industrial policy with stricter climate action requires high capital investments [199]. Increased costs and fear of carbon leakage constitute two existing barriers for effective legislative initiatives, threatening to cause insufficient prioritisation to implement policies on decarbonising energy-intensive industries. Industrial transition is heavily dependent on strictly-committing emissions mitigation policy [85]. Lack of willingness to propose coherent industrial policies may result in 
institutional failures of both systems endangering decarbonisation. This structural failure at early stages can potentially evolve into a transformational directionality failure [96] as the transition unfolds due to lack of strategic guidance.

Additional institutional challenges are present in the UK, because of Brexit, which may increase volatility on a policy level, resulting in either looser or stricter legislative landscape. The country's autonomy to form its own legislation without restrictions from a supranational body means it will have to abide by its own easily modifiable laws. Hence, the pathway that governmental authorities choose may significantly affect industrial decarbonisation. Furthermore, it is now easier for businesses to transfer key activities abroad, than when part of the EU, thereby increasing carbon leakage fears.

\subsection{Capabilities}

System failures also emerge from firms' unwillingness or inability to adjust to new technological and environmental standards. Industrial transitions require the necessary financial and technological resources, flexibility and learning capacity, usually related to the development capability of a corporation [22]. Industries require high capital costs for any type of investment regarding equipment modification [199]. Long investment cycles imply significant delays before return of the capital invested [200]. Diffusion of technologies like hydrogen, struggling to be financially competitive [201], are further affected by such cycles. This is a significant barrier for every industry, especially in shrinking markets, like the UK, which is more susceptible to capability system failures.

Another significant barrier to industrial decarbonisation lies in energy-intensive industries supplying others that are generally reluctant to use low- or zero-carbon material due to lower short-term returns [83]. This reluctance in turn does not motivate industrial sub-sectors to decarbonise practices and products. Lack of dedication is strengthened by other major exporting countries, like China, providing cheaper commodities, since they engage to less energy efficiency investments and industrial environmental upgrades [202]. Consequently, the UK and German industrial systems alike may hesitate to adapt to green technologies, to compete with non-European exporters possessing a competitive edge. China's expansion poses a significant challenge for UK economy, due to the lengthy period of its shift towards services, accompanied by a continuous industrial downfall, and coupled with Brexit volatilities and subsequent efforts from other European countries to increase their services share [203,204]. Even though some of the challenges are shared by Germany, the latter's sector has shown resilience, demonstrating stability supported by eminent automotive and construction sectors, especially for iron and steel. Said challenge for UK industry is augmented by willingness of Chinese investors to penetrate the British market, by investing in existing industrial plants [205], with growing uncertainty regarding the future of UK iron and steel enterprises. UK policy should therefore focus on incentivising new industries and players in green markets, while linking energy-intensive manufacturing to domestic production of low-carbon technologies like wind turbines.

German industry appears more robust regarding demand-side capabilities bottlenecks, compared to the UK, due to high influence of demand; nonetheless, dependency on specific midstream sectors (e.g., automotive) means that, if these sectors face production decline, upstream industry will also encounter sales cuts, making it vulnerable.

Regarding actor-side capabilities, comparison on technology focuses on the knowledge base employed by each sub-sector in the two countries. BF dominates iron and steel production, while the more efficient EAF is more widespread in Germany (30\%) than the UK (17\%) [138,177]. Hence, German iron and steel industry already features stronger decarbonisation technologies resulting in lower $\mathrm{CO}_{2}$ intensity. Cement is characterised by a single technology used in both countries. However, a distinction is made based on the fuel consumed; biomass and waste are used in $40 \%$ of UK's total energy consumed, lower than Germany's $60 \%$, a difference partly attributed to technical and environmental requirements for different materials [141]. Nevertheless, UK cement $\mathrm{CO}_{2}$ intensity is lower than Germany's due to a substantial share of natural gas in clinker production. 
Apart from existing technologies, knowledge diffusion of carbon-free technologies in industry also faces challenges. Considered technologies include low- or zero-carbon hydrogen use in various industrial procedures, and CCS, with the new UK Budget 2020 promising to establish a fund for financing two CCS installations [168]. Since none of the countries has yet implemented such technologies, examination of potential failures on an innovation level is inconclusive, although high investment costs threaten the ability to financially support them. The UK has been an important driver of hydrogen use and research [185], while in Germany many energy-intensive industrial firms have shown interest in a hydrogen strategy. Incompatibility between electrification techniques like EAF with CCS could act as barriers to expansion of their application, with CCS being in early stages in both countries. Less invasive technologies reducing emissions, like BAT, can be further implemented in both countries [183] but feature limitations in achieving long-term targets.

\subsection{Infrastructure}

The last component of the system failures framework regards available infrastructure, which can be separated in two categories [206]: external factors and general infrastructure, like energy and communication networks; internal technological infrastructure like the existence of testing facilities. Both countries are considered among the most economically and technologically developed countries worldwide. Therefore, both countries experience resilience toward infrastructural failures.

\section{Conclusions}

This research aims to review the German and UK industrial sectors from an innovation system perspective, to understand drivers of and barriers to entry of new, sustainable technologies and translate them into policy implications. While their total $\mathrm{CO}_{2}$ emissions have continuously reduced in the UK, they have been stalling in Germany since 2000. The analysis is focused on the energy-intensive sub-sectors of iron and steel, cement and chemicals, representing most industrial $\mathrm{CO}_{2}$ emissions in both countries. Recent emissions cuts are shown to mainly stem from shrinking activity, while limited decrease of carbon intensity implies low diffusion of low-carbon technologies. By implementing the SIS framework, the role of actors, institutions, demand and knowledge is examined for both countries; further combining the SIS structural elements with the system failures framework helps identify existing or potential risks for the diffusion of innovative technologies related to sectoral decarbonisation.

The iron and steel industry has been a main driver for Germany's economy, providing the necessary materials for the domestic automotive industry, affecting multitudinous value chains. These business-to-business networks between companies in each sub-sector and their respective consumers constitute strong demand influence on the German innovation system. Even though different interests exist inside the system, large corporations, coupled with powerful associations with impact on global industry, lead to stable economic activity of German industry, although strong networks present occasional challenges, with the capacity to delay environmental regulation affecting transition towards greener technologies. However, this observed balance is not equally reflected in UK industry: its ongoing transition from an industrial towards a service-based economy poses major threats for the system, progressively leading to shrinking economic activity, additionally facing Brexit-related uncertainties. However, partial deindustrialisation of the economy has weakened the regime, contrary to Germany, which has not yet resulted in substantial changes in carbon intensities but presents an opportunity for new businesses with innovative sustainable processes to emerge and benefit from the downturn [207].

This critical difference allowed a comparative analysis of the two countries to provide valuable insights into existing challenges incommoding creation and effective diffusion of innovation, but also into potential challenges in the UK that the stable German system is not yet experiencing. China's competing role as a significant barrier is frequently raised, since different domestic mechanisms and conditions keep prices low and threaten the examined industrial systems. This competitive edge, also valid for other emerging economies, affects UK and German manufacturers, increasing imports, 
while decreasing demand for domestic supply. This effect is stronger in the UK, since the automotive industry helps Germany's industry withstand pressure and retain shares, but further international competition may act as a disruptive force against this stability. Addressing the issue both at national and European level has led to institutional inconsistencies, since strict emissions targets needed to be relaxed through free allowances for industrial sectors to boost competitiveness, acting as a bottleneck for innovative technologies, allowing the regime to retain currently energy-intensive processes. This is a plausible explanation for little progress in reducing $\mathrm{CO}_{2}$ intensity in most energy-intensive sectors indicating that the transition is still at very early stages.

As showcased in our analysis, transition of the examined industries cannot be driven automatically by the actors, who even push for more lenient targets, since there is no universal opportunity providing huge financial incentives. Future policies need to address this hesitation by applying stricter targets for the industrial sector. A stricter EU-ETS regulation can provide this incentive to guide the transition, since stricter policies are usually correlated with boost of innovation [208]. Simultaneously, fear of carbon leakage can be limited through policy actions, like carbon border tax adjustments to boost competitiveness of specific sectors [209], or European countries mostly affected by production relocations [210]. Occasional opportunities for emerging green technologies, such as the use of blue or green hydrogen and CCS can be exploited, since they already receive significant private-sector interest. Industrial policies must have a clear strategy for sustainable transition, providing ways to finance such technologies addressing the high investment costs required. It is also necessary for these transition costs to spread through the entire value-chain and be evenly distributed among state and actors, who hitherto showcased reluctance. Moreover, future policy decisions on the industrial decarbonisation roadmap to follow independently or in collaboration with the EU need to address Brexit-institutional uncertainties and assist new players launch innovative entrepreneurial activities.

Our research can be further enhanced by combining the SIS approach with other Systems of Innovation frameworks: an integrative approach will allow for a holistic perspective of the examined systems in transition, while overcoming the limitations of each framework [211]. Such frameworks include the MLP, which has also been used to draw comparisons between the UK and Germany in the transport sector [212] and analyse the German electricity market [213]; system mapping [53], which provides the opportunity to both examine interactions regarding innovation diffusion and evaluate the broader context of landscape and regime as part of a sustainable systemic transformation of the two countries; or different combinations of innovation frameworks [214,215]. Another prospect lies in expanding the SIS analysis to include the diversity of industrial sub-sectors and therefore unfold the national industries in their entirety, thereby allowing to examine cross-sectoral interconnections that may promote or hinder the deployment of innovative, collectively beneficial, and non-conflicting technologies. As transition of the energy-intensive industries progresses in the near future, focus can later be given on specific technological processes, by applying the TIS framework [48] and expand the system failures framework to include the transitional failures proposed by [96]. Finally, Systems of Innovation frameworks have been gaining attention both as climate policy support frameworks [216] and as part of integrative approaches $[217,218]$ : policy implications provided in this study can be coupled with modelled future mitigation pathways [219] to highlight bottlenecks in the industrial sectors examined in this research, and to formulate recommendations on designing transformative policy pathways overcoming them $[220,221]$, as has recently been the case with other qualitative frameworks in relevant industrial case studies [222,223] or otherwise [224,225].

Author Contributions: Conceptualization, A.N., K.K. and H.N.; methodology, K.K., H.N. and A.K.; validation, A.G., J.W. and A.N.; formal analysis, K.K., A.K., H.N. and A.N.; data curation, K.K., A.K., and J.W.; writing-original draft preparation, K.K., A.K., H.N., A.N. and H.D.; writing-review and editing, K.K., A.G., and A.N.; visualization, K.K., J.W., H.N. and A.N.; supervision, A.N. and H.D.; project administration, H.D. All authors have read and agreed to the published version of the manuscript.

Funding: This research was funded by European Commission Horizon 2020 Framework Programme, 'PARIS REINFORCE' Research and Innovation Project, grant number 820846 . The APC was funded by the National Technical University of Athens. 
Acknowledgments: The most important part of this research is based on the H2020 European Commission Project "PARIS REINFORCE" under grant agreement No. 820846. The sole responsibility for the content of this paper lies with the authors. The paper does not necessarily reflect the opinion of the European Commission. The authors would like to thank Christos Petkidis for his copyediting work.

Conflicts of Interest: The authors declare no conflict of interest. The funders had no role in the design of the study; in the collection, analyses, or interpretation of data; in the writing of the manuscript, or in the decision to publish the results.

\section{Appendix A}

The activities corresponding to the examined sectors include Division 20 for the manufacturing of chemicals, Group 241 and Class 2431 for the iron and steel industry and 2394 for manufacturing of cement in accordance with the 4th revision of the International Standard Industrial Classification of All Economic Activities (ISIC) [226], which are in line with the UNFCCC classification for counting emissions in the different sectors.

Production of steel is currently based on two main routes: the primary method of Blast Furnace/Basic Oxygen Furnace (BF-BOF), producing steel directly from iron ores, and Electric Arc Furnace (EAF), producing steel from scrap. $70.7 \%$ of total steel production is based on BF-BOF, while $28.9 \%$ on EAF [227]. As of 2018, the EU relied substantially more on EAF than the global average, producing $41.7 \%$ of crude steel via this method, while BF-BOF accounted for $51.3 \%$ [228]. Direct Reduced Iron (DRI) and Smelting Iron (COREX and FINEX methods) could feed into the EAF process, accounting for $5 \%$, with a small number of power plants globally [139].

Via the BF-BOF route, iron ores are sintered and pelletised to prepare iron oxide raw materials, while hard coal is carbonised in high temperatures in coke ovens, to be converted into coke, a strong carbonaceous material [229]. These materials are then fed from the top of the blast furnace (BF). The iron-bearing materials, reducing agents and additive materials like limestone are blasted via tuyeres with hot air enriched with oxygen, to reduce iron oxides and create the hot metal (pig iron) [230]. The hot air reacts with the reducing agents to create carbon monoxide, which in turn helps reduce iron oxide to pig iron; a by-product of the chemical reactions is $\mathrm{CO}_{2}$, meaning that $\mathrm{BF}$ is an important contributor of carbon-based emissions. Even though partial use of coke can be replaced by other hydrocarbons creating less emissions, an amount of coke should always be used to maintain the BF operation [111]. Contrary to BF-BOF, which produces steel directly from iron ores, EAF uses recycled steel scrap-steel is easily recycled. Even though it requires significant amounts of electricity, this process is more efficient than BF-BOF, requiring almost one-third of energy [139]. DRI can also be used for the important iron ore reduction, with scrap availability otherwise limiting EAF [149]. Using natural gas instead of coke, DRI can lead to significantly lower $\mathrm{CO}_{2}$ emissions [231]. Production of hot metal from iron ore can be achieved without coke through smelting reduction as an alternative to $\mathrm{BF}$, thus avoiding the environmental impacts of coke ovens and sinter plants by using non-coke coal reducing agents [232]. However, higher fuel consumption of processes like COREX and FINEX acts as a barrier to popularisation of these techniques [233].

According to the Best Available Techniques (BAT) report of the European Commission [111], processes of iron and steel production lead to emissions of off-gases and solid waste through most of the necessary steps. Coal and coke handling plays a significant role in these emissions, but raw material handling and transportation or energy required for operation of facilities and heating of equipment could also contribute. Environmental harm also derives from slag created in BF, BOF and EAF, which is usually collected and then used as construction material or in road building $[234,235]$.

Being essential for the building sector, cement is considered one of the most significant materials in the world. It is the main ingredient for producing concrete, a blend of inert mineral aggregates [236]. The most used type of cement is Portland cement, accounting for approximately $90 \%$ of global production; other types are also produced similarly yet characterised by different ingredient mixes [237]. Cement production consists of four steps: mining and quarrying, kiln feed preparation, clinker production (pyro-processing) and finish grinding. The basic ingredient used for manufacturing cement 
is calcium carbonate, obtained by limestone or chalk [238], which are usually mined from a quarry near the cement plant [236]. There exist other minerals mined for producing cement, like clay and shale, which are used for generating other ingredients necessary for the mix. During pyro-processing in kiln, various chemical reactions occur, such as evaporation of free water and calcination of calcium carbonate, taking place in four zones, all characterised by high temperatures; the most important is decomposition of calcium carbonate [239]. The remaining reactions result in enrichment of calcium oxide to produce clinker, which is the main cement ingredient. This material must be cooled before being blended with the required additives for producing cement. Heating the kiln requires significant amounts of energy, usually from fossil fuel combustion. During grinding, clinker is combined with various additives to adjust its properties, which are also dependent on the energy consumed during grinding, since high quality product requires higher amount of energy used.

In chemicals, there is a diverse range of final products that arise from a handful of basic materials, which creates difficulties presenting a dominant business-as-usual process.

\section{References}

1. IPCC. Mitigation of Climate Change. Contribution of Working Group III to the Fifth Assessment Report of the Intergovernmental Panel on Climate Change. 2014. Available online: https:/www.ipcc.ch/site/assets/ uploads/2018/02/ipcc_wg3_ar5_chapter10.pdf (accessed on 19 March 2020).

2. Åhman, M.; Nilsson, L.J. Decarbonizing industry in the EU: Climate, trade and industrial policy strategies. In Decarbonization in the European Union; Palgrave Macmillan: London, UK, 2015; pp. 92-114.

3. Gerres, T.; Chaves Ávila, J.; Llamas, P.; San Román, T. A review of cross-sector decarbonisation potentials in the European energy intensive industry. J. Clean. Prod. 2019, 210, 585-601. [CrossRef]

4. Pardo, N.; Moya, J.A. Prospective scenarios on energy efficiency and $\mathrm{CO}_{2}$ emissions in the European Iron \& Steel industry. Energy 2013, 54, 113-128.

5. Stefana, E.; Cocca, P.; Marciano, F.; Rossi, D.; Tomasoni, G. A Review of Energy and Environmental Management Practices in Cast Iron Foundries to Increase Sustainability. Sustainability 2019, 11, 7245. [CrossRef]

6. Karakaya, E.; Nuur, C.; Assbring, L. Potential transitions in the iron and steel industry in Sweden: Towards a hydrogen-based future? J. Clean. Prod. 2018, 195, 651-663. [CrossRef]

7. Wesseling, J.H.; Lechtenböhmer, S.; Åhman, M.; Nilsson, L.J.; Worrell, E.; Coenen, L. The transition of energy intensive processing industries towards deep decarbonisation: Characteristics and implications for future research. Renew. Sustain. Energy Rev. 2017, 79, 1303-1313. [CrossRef]

8. Flichy, P. Understanding Technological Innovation: A Socio-technical Approach; Edward Elgar Publishing: Cheltenham, UK, 2008.

9. Mokhtar, A.; Nasooti, M. A decision support tool for cement industry to select energy efficiency measures. Energy Strategy Rev. 2020, 28, 100458. [CrossRef]

10. Avami, A.; Sattari, S. Energy conservation opportunities: Cement industry in Iran. Int. J. Energy 2007, 1, 65-71.

11. Markewitz, P.; Zhao, L.; Ryssel, M.; Moumin, G.; Wang, Y.; Sattler, C.; Robinius, M.; Stolten, D. Carbon Capture for $\mathrm{CO}_{2}$ Emission Reduction in the Cement Industry in Germany. Energies 2019, 12, 2432. [CrossRef]

12. Griffin, P.W.; Hammond, G.P.; Norman, J.B. Industrial energy use and carbon emissions reduction in the chemicals sector: A UK perspective. Appl. Energy 2018, 227, 587-602. [CrossRef]

13. Allen, J. Towards a post-industrial economy. In The Economy in Question; Allen, J., Massey, D., Eds.; Sage: London, UK, 1998; pp. 91-135.

14. Cunningham, I.; James, P. The outsourcing of social care in Britain: What does it mean for voluntary sector workers? Work Employ. Soc. 2009, 23, 363-375. [CrossRef]

15. Edquist, C.; Hommen, L.; McKelvey, M.D. Innovation and Employment: Process versus Product Innovation; Edward Elgar Publishing: Cheltenham, UK, 2001.

16. Fagerberg, J.; Mowery, D.C.; Nelson, R.R. (Eds.) The Oxford Handbook of Innovation; Oxford University Press: Oxford, UK, 2005. 
17. Song, L.; Lieu, J.; Nikas, A.; Arsenopoulos, A.; Vasileiou, G.; Doukas, H. Contested energy futures, conflicted rewards? Examining low-carbon transition risks and governance dynamics in China's built environment. Energy Res. Soc. Sci. 2020, 59, 101306. [CrossRef]

18. Edquist, C. Systems of Innovation: Perspectives and Challenges. In The Oxford Handbook of Innovation; Fagerberg, J., Mowery, D.C., Nelson, R.R., Eds.; Oxford University Press: Oxford, UK, 2005; pp. 181-208.

19. Malerba, F. (Ed.) Sectoral Systems of Innovation: Concepts, Issues and Analyses of Six Major Sectors in Europe; Cambridge University Press: Cambridge, UK, 2004.

20. Malerba, F. Sectoral systems of innovation and production. Res. Policy 2002, 31, 247-264. [CrossRef]

21. Bosman, R.; Loorbach, D.; Rotmans, J.; Van Raak, R. Carbon lock-out: Leading the fossil port of Rotterdam into transition. Sustainability 2018, 10, 2558. [CrossRef]

22. Woolthuis, R.K.; Lankhuizen, M.; Gilsing, V. A system failure framework for innovation policy design. Technovation 2005, 25, 609-619. [CrossRef]

23. Marçal, E.F.; de Prince, D.; Zimmermann, B.; Merlin, G.; Simões, O. Assessing global economic activity linkages: The role played by United States, Germany and China. EconomiA 2020, 21, 38-56. [CrossRef]

24. Statista. United Kingdom: Distribution of Gross Domestic Product (GDP) Across Economic Sectors from 2008 to 2018. 2018. Available online: https://www.statista.com/statistics/270372/distribution-of-gdp-acrosseconomic-sectors-in-the-united-kingdom/ (accessed on 10 July 2020).

25. Tamanini, J.; Bassi, A.; Hoffman, C.; Valeciano, J. The Global Green Economy Index GGEI 2014. In Measuring National Performance in the Green Economy 4th Edition-October; Dual Citizen: New York, NY, USA, 2014.

26. OECD. Gross Domestic Spending on R\&D. 2017. Available online: https://data.oecd.org/rd/gross-domesticspending-on-r-d.htm (accessed on 15 May 2020).

27. IEA. Data and Statistics. 2019. Available online: https://www.iea.org/data-and-statistics/data-tables? country=WORLD\&energy=Balances\&year=2017 (accessed on 10 April 2020).

28. UNFCCC. Greenhouse Gas Inventory Data. 2018. Available online: https://di.unfccc.int/detailed_data_by_ party (accessed on 18 July 2020).

29. Zeng, B.; Zhu, L. Market Power and Technology Diffusion in an Energy-Intensive Sector Covered by an Emissions Trading Scheme. Sustainability 2019, 11, 3870. [CrossRef]

30. BGS. Mineral Planning Factsheet: Cement Raw Materials. Available online: https: $/ /$ www.google.com.hk/url? sa =t\&rct=j\&q=\&esrc=s\&source=web\&cd=\&ved=2ahUKEwiM2KU4fvrAhVAy4sBHbHUA78QFjAAegQIAxAB\&url=https\%3A\%2F\%2Fwww.bgs.ac.uk\%2Fdownloads\% 2Fstart.cfm\%3Fid\%3D1353\&usg=AOvVaw2dVh6Sj35hxNqDdzplAFbP (accessed on 15 March 2020).

31. Schettkat, R.; Yocarini, L. The shift to services employment: A review of the literature. Struct. Chang. Econ. Dyn. 2006, 17, 127-147. [CrossRef]

32. Office for National Statistics. Changes in the Economy Since the 1970s. 2019. Available online: https:/www.ons.gov.uk/economy/economicoutputandproductivity/output/articles/ changesintheeconomysincethe1970s/2019-09-02 (accessed on 2 June 2020).

33. Kaya, Y.; Yokobori, K. (Eds.) Environment, Energy, and Economy: Strategies for Sustainability; United Nations University Press: Tokyo, Japan, 1997.

34. Wachsmuth, J.; Duscha, V. Achievability of the Paris targets in the EU-The role of demand-side-driven mitigation in different types of scenarios. Energy Effic. 2019, 12, 403-421. [CrossRef]

35. Mantzos, L.; Matei, N.; Mulholland, E.; Rózsai, M.; Tamba, M.; Wiesenthal, T. JRC-IDEES 2015. European Commission, Joint Research Centre (JRC) [Dataset] PID. 2018. Available online: http://data.europa.eu/89h/ jrc-10110-10001 (accessed on 30 May 2020).

36. Hekkert, M.P.; Suurs, R.A.; Negro, S.O.; Kuhlmann, S.; Smits, R.E. Functions of innovation systems: A new approach for analysing technological change. Technol. Forecast. Soc. Chang. 2007, 74, 413-432. [CrossRef]

37. Nelson, R.; Winter, S.G. An Evolutionary Theory of Economic Change; Harvard University Press: Cambridge, MA, USA, 1982.

38. Nelson, R.R.; Nelson, K. Technology, institutions, and innovation systems. Res. Policy 2002, 31, $265-272$. [CrossRef]

39. Callon, M. Society in the making: The study of technology as a tool for sociological analysis. In The Social Construction of Technological Systems: New Directions in the Sociology and History of Technology; MIT Press: Cambridge, MA, USA, 1987; pp. 83-103. 
40. Freeman, C. Technology, Policy, and Economic Performance: Lessons from Japan; Pinter Publishers: London, UK, 1987.

41. Lundvall, B.A. National Systems of Innovation: Towards a Theory of Innovation and Interactive Learning; Pinter Publishers: London, UK, 1992.

42. Nelson, R.R. (Ed.) National Innovation Systems: A Comparative Analysis; Oxford University Press: Oxford, UK, 1993.

43. Asheim, B.T.; Isaksen, A. Location, agglomeration and innovation: Towards regional innovation systems in Norway? Eur. Plan. Stud. 1997, 5, 299-330. [CrossRef]

44. Cooke, P.; Uranga, M.G.; Etxebarria, G. Regional innovation systems: Institutional and organisational dimensions. Res. Policy 1997, 26, 475-491. [CrossRef]

45. Cooke, P. Regional innovation systems, clusters, and the knowledge economy. Ind. Corp. Chang. 2001, 10, 945-974. [CrossRef]

46. Breschi, S.; Malerba, F. Sectoral innovation systems: Technological regimes, Schumpeterian dynamics, and spatial boundaries. In Systems of Innovation: Technologies, Institutions and Organizations; Edquist, C., Ed.; Pinter Publisher: London, UK, 1997; pp. 130-156.

47. Malerba, F. Sectoral systems of innovation: A framework for linking innovation to the knowledge base, structure and dynamics of sectors. Econ. Innov. New Technol. 2005, 14, 63-82. [CrossRef]

48. Carlsson, B.; Stankiewicz, R. On the nature, function and composition of technological systems. J. Evol. Econ. 1991, 1, 93-118. [CrossRef]

49. Asheim, B.T.; Smith, H.L.; Oughton, C. Regional innovation systems: Theory, empirics and policy. Reg. Stud. 2011, 45, 875-891. [CrossRef]

50. Frenz, M.; Oughton, C. Innovation in the UK Regions and Devolved Administrations: A Review of the Literatura; Final Report for the Department of Trade and Industry and the Office of the Deputy Prime Minister; DTI: London, UK, 2005.

51. Binz, C.; Truffer, B. Global Innovation Systems-A conceptual framework for innovation dynamics in transnational contexts. Res. Policy 2017, 46, 1284-1298. [CrossRef]

52. Bergek, A.; Jacobsson, S.; Carlsson, B.; Lindmark, S.; Rickne, A. Analyzing the functional dynamics of technological innovation systems: A scheme of analysis. Res. Policy 2008, 37, 407-429. [CrossRef]

53. Nikas, A.; Doukas, H.; Lieu, J.; Tinoco, R.A.; Charisopoulos, V.; van der Gaast, W. Managing stakeholder knowledge for the evaluation of innovation systems in the face of climate change. J. Knowl. Manag. 2017, 21, 1013-1034. [CrossRef]

54. Albu, M.; Griffith, A. Mapping the Market: A Framework for Rural Enterprise Development Policy and Practice; Practical Action: Rugby, UK, 2005.

55. Markard, J.; Truffer, B. Technological innovation systems and the multi-level perspective: Towards an integrated framework. Res. Policy 2008, 37, 596-615. [CrossRef]

56. Rip, A.; Kemp, R. Technological change. Hum. Choice Clim. Chang. 1998, 2, 327-399.

57. Geels, F.W. Technological transitions as evolutionary reconfiguration processes: A multi-level perspective and a case-study. Res. Policy 2002, 31, 1257-1274. [CrossRef]

58. Chung, C.C. National, sectoral and technological innovation systems: The case of Taiwanese pharmaceutical biotechnology and agricultural biotechnology innovation systems (1945-2000). Sci. Public Policy 2012, 39, 271-281. [CrossRef]

59. Rogge, K.S.; Hoffmann, V.H. The impact of the EU ETS on the sectoral innovation system for power generation technologies-Findings for Germany. Energy Policy 2010, 38, 7639-7652. [CrossRef]

60. Siva, V.; Hoppe, T.; Jain, M. Green buildings in Singapore; analyzing a frontrunner's sectoral innovation system. Sustainability 2017, 9, 919. [CrossRef]

61. Kim, Y.Z.; Lee, K. Sectoral innovation system and a technological catch-up: The case of the capital goods industry in Korea. Glob. Econ. Rev. 2008, 37, 135-155. [CrossRef]

62. Sæther, B.; Isaksen, A.; Karlsen, A. Innovation by co-evolution in natural resource industries: The Norwegian experience. Geoforum 2011, 42, 373-381. [CrossRef]

63. Andersen, P.D.; Andersen, A.D.; Jensen, P.A.; Rasmussen, B. Sectoral innovation system foresight in practice: Nordic facilities management foresight. Futures 2014, 61, 33-44. [CrossRef] 
64. Balaguer, A.; Marinova, D. Sectoral Transformation in the Photovoltaics Industry in Australia, Germany and Japan: Contrasting the Co-evolution of Actors, Knowledge, Institutions and Markets. Prometheus 2006, 24, 323-339. [CrossRef]

65. Chunhavuthiyanon, M.; Intarakumnerd, P. The role of intermediaries in sectoral innovation system: The case of Thailand's food industry. Int. J. Technol. Manag. Sustain. Dev. 2014, 13, 15-36. [CrossRef]

66. Faber, A.; Hoppe, T. Co-constructing a sustainable built environment in the Netherlands-Dynamics and opportunities in an environmental sectoral innovation system. Energy Policy 2013, 52, 628-638. [CrossRef]

67. Lechtenböhmer, S.; Nilsson, L.J.; Åhman, M.; Schneider, C. Decarbonising the energy intensive basic materials industry through electrification-Implications for future EU electricity demand. Energy 2016, 115, 1623-1631. [CrossRef]

68. Åhman, M.; Nikoleris, A.; Nilsson, L.J. Decarbonising Industry in Sweden; IMES/EES report no 77; Lund University: Lund, Sweden, 2012; Volume 77.

69. Wesseling, J.H.; Van der Vooren, A. Lock-in of mature innovation systems: The transformation toward clean concrete in the Netherlands. J. Clean. Prod. 2017, 155, 114-124. [CrossRef]

70. Coenen, L.; López, F.J.D. Comparing systems approaches to innovation and technological change for sustainable and competitive economies: An explorative study into conceptual commonalities, differences and complementarities. J. Clean. Prod. 2010, 18, 1149-1160. [CrossRef]

71. Geels, F.W. From sectoral systems of innovation to socio-technical systems: Insights about dynamics and change from sociology and institutional theory. Res. Policy 2004, 33, 897-920. [CrossRef]

72. Markusen, A. Des lieux-aimants dans un espace mouvant: Une typologie des districts industriels. La Rich. Des Régions 2000, 85-119.

73. Esparcia, J. Innovation and networks in rural areas. Anal. Eur. Innov. Projects. J. Rural Stud. 2014, 34, 1-14. [CrossRef]

74. Napp, T.A.; Gambhir, A.; Hills, T.P.; Florin, N.; Fennell, P.S. A review of the technologies, economics and policy instruments for decarbonising energy-intensive manufacturing industries. Renew. Sustain. Energy Rev. 2014, 30, 616-640. [CrossRef]

75. Klepper, S.; Malerba, F. Demand, innovation and industrial dynamics: An introduction. Ind. Corp. Chang. 2010, 19, 1515-1520. [CrossRef]

76. Turnbull, P.; Oliver, N.; Wilkinson, B. Buyer-supplier relations in the UK-automotive industry: Strategic implications of the Japanese manufacturing model. Strateg. Manag. J. 1992, 13, 159-168. [CrossRef]

77. Mazur, C.; Contestabile, M.; Offer, G.J.; Brandon, N.P. Understanding the drivers of fleet emission reduction activities of the German car manufacturers. Environ. Innov. Soc. Transit. 2015, 16, 3-21. [CrossRef]

78. Malerba, F.; Orsenigo, L. Technological regimes and sectoral patterns of innovative activities. Ind. Corp. Chang. 1997, 6, 83-118. [CrossRef]

79. Unruh, G.C. Understanding carbon lock-in. Energy Policy 2000, 28, 817-830. [CrossRef]

80. Zhang, J.; Liang, X.J. Promoting green ICT in China: A framework based on innovation system approaches. Telecommun. Policy 2012, 36, 997-1013. [CrossRef]

81. Bento, N.; Fontes, M. Spatial diffusion and the formation of a technological innovation system in the receiving country: The case of wind energy in Portugal. Environ. Innov. Soc. Transit. 2015, 15, 158-179. [CrossRef]

82. Andersen, A.D.; Markard, J. Multi-technology interaction in socio-technical transitions: How recent dynamics in HVDC technology can inform transition theories. Technol. Forecast. Soc. Chang. 2020, 151, 119802. [CrossRef]

83. Janipour, Z.; de Nooij, R.; Scholten, P.; Huijbregts, M.A.; de Coninck, H. What are sources of carbon lock-in in energy-intensive industry? A case study into Dutch chemicals production. Energy Res. Soc. Sci. 2020, 60, 101320. [CrossRef]

84. Åhman, M.; Nilsson, L.J.; Johansson, B. Global climate policy and deep decarbonisation of energy-intensive industries. Clim. Policy 2017, 17, 634-649. [CrossRef]

85. Bataille, C.; Åhman, M.; Neuhoff, K.; Nilsson, L.J.; Fischedick, M.; Lechtenböhmer, S.; Solano-Rodriquez, B.; Denis-Ryan, A.; Stiebert, S.; Waisman, H.; et al. A review of technology and policy deep decarbonization pathway options for making energy-intensive industry production consistent with the Paris Agreement. J. Clean. Prod. 2018, 187, 960-973. [CrossRef]

86. Dewald, U.; Achternbosch, M. Why more sustainable cements failed so far? Disruptive innovations and their barriers in a basic industry. Environ. Innov. Soc. Transit. 2016, 19, 15-30. [CrossRef] 
87. Luiten, E.E.; Blok, K. Stimulating R\&D of industrial energy-efficient technology; the effect of government intervention on the development of strip casting technology. Energy Policy 2003, 31, 1339-1356.

88. Foxon, T.; Pearson, P. Overcoming barriers to innovation and diffusion of cleaner technologies: Some features of a sustainable innovation policy regime. J. Clean. Prod. 2008, 16, S148-S161. [CrossRef]

89. Brown, M.A. Market failures and barriers as a basis for clean energy policies. Energy Policy 2001, 29, 1197-1207. [CrossRef]

90. Foxon, T.J.; Gross, R.; Chase, A.; Howes, J.; Arnall, A.; Anderson, D. UK innovation systems for new and renewable energy technologies: Drivers, barriers and systems failures. Energy Policy 2005, 33, 2123-2137. [CrossRef]

91. Perel, M. One Point of View: Corporate Courage: Breaking the Barrier to Innovation. Res. Technol. Manag. 2002, 45, 9-17. [CrossRef]

92. Koasidis, K.; Karamaneas, A.; Nikas, A.; Neofytou, H.; Hermansen, E.A.; Vaillancourt, K.; Doukas, H. Many Miles to Paris: A Sectoral Innovation System Analysis of the Transport Sector in Norway and Canada in Light of the Paris Agreement. Sustainability 2020, 12, 5832. [CrossRef]

93. Carlsson, B.; Jacobsson, S. In search of useful public policies-Key lessons and issues for policy makers. In Technological Systems and Industrial Dynamics; Springer: Boston, MA, USA, 1997; pp. 299-315.

94. Lundvall, B.A. Innovation as an interactive process. In The Learning Economy and the Economics of Hope; Anthem Press: London, UK, 2016; pp. 61-84.

95. Jack, S.L. The role, use and activation of strong and weak network ties: A qualitative analysis. J. Manag. Stud. 2005, 42, 1233-1259. [CrossRef]

96. Weber, K.M.; Rohracher, H. Legitimizing research, technology and innovation policies for transformative change: Combining insights from innovation systems and multi-level perspective in a comprehensive 'failures' framework. Res. Policy 2012, 41, 1037-1047. [CrossRef]

97. Giugni, M. Social Protest and Policy Change: Ecology, Antinuclear, And Peace Movements in Comparative Perspective; Rowman \& Littlefield: Lanham, MD, USA, 2004.

98. Gutberlet, T. Mechanization, Transportation, and the Location of Industry in Germany 1846 to 1907. Ph.D. Thesis, University of Arizona, Tucson, AZ, USA, 2013.

99. Fernihough, A.; O’Rourke, K.H. Coal and the European Industrial Revolution (No. w19802); National Bureau of Economic Research: Cambridge, MA, USA, 2014.

100. Schuetze, A.; Seythal, T. German antitrust watchdog fines Thyssen, Salzgitter, Voestalpine. Reuters. 2019. Available online: https://www.reuters.com/article/us-germany-steel/german-antitrust-watchdog-finesthyssen-salzgitter-voestalpine-idUSKBN1YG0UA (accessed on 12 December 2019).

101. Hasanbeigi, A.; Arens, M.; Price, L. Alternative emerging ironmaking technologies for energy-efficiency and carbon dioxide emissions reduction: A technical review. Renew. Sustain. Energy Rev. 2014, 33, 645-658. [CrossRef]

102. Schmidt, S.; Minssen, H. Accounting for international assignments: The case of the German chemical industry. J. Hum. Resour. Costing Account. 2007, 11, 214-228. [CrossRef]

103. Kahl, R.; Desel, H. Germany: Toxicology information on the World Wide Web. Toxicology 2003, 190, $23-33$. [CrossRef]

104. Markussen, P.; Svendsen, G.T. Industry lobbying and the political economy of GHG trade in the European Union. Energy Policy 2005, 33, 245-255. [CrossRef]

105. Liebmann, H.; Kuder, T. Pathways and strategies of urban regeneration-Deindustrialized cities in eastern Germany. Eur. Plan. Stud. 2012, 20, 1155-1172. [CrossRef]

106. IEA. Electricity Feed-In Law of 1991 (“Stromeinspeisungsgesetz"). 2013. Available online: https://www.iea. org/policies/3477-electricity-feed-in-law-of-1991-stromeinspeisungsgesetz (accessed on 14 March 2020).

107. Lauber, V.; Jacobsson, S. The politics and economics of constructing, contesting and restricting socio-political space for renewables-The German Renewable Energy Act. Environ. Innov. Soc. Transit. 2016, 18, 147-163. [CrossRef]

108. Renn, O.; Marshall, J.P. Coal, nuclear and renewable energy policies in Germany: From the 1950s to the "Energiewende". Energy Policy 2016, 99, 224-232. [CrossRef]

109. Hartung, J. Rules and regulations related to preventing pollution from animal manure in the Federal Republic of Germany. Agric. Ecosyst. Environ. 1986, 16, 273-279. [CrossRef] 
110. Drotloff, H. Reduction of Emissions by Chemical Industry from the German Emission Control Act to the Industrial Emission Directive (IED). Procedia Technol. 2014, 12, 637-642. [CrossRef]

111. Roudier, S.; Sancho, L.D.; Remus, R.; Aguado-Monsonet, M. Best Available Techniques (BAT) Reference Document for Iron and Steel Production: Industrial Emissions Directive 2010/75/EU: Integrated Pollution Prevention and Control (No. JRC69967); Joint Research Centre (Seville site): Brussels, Belgium, 2013.

112. Conti, M.E.; Ciasullo, R.; Tudino, M.B.; Matta, E.J. The industrial emissions trend and the problem of the implementation of the Industrial Emissions Directive (IED). Air Qual. Atmos. Health 2015, 8, 151-161. [CrossRef]

113. Graichen, V.; Schumacher, K.; Matthes, F.C.; Mohr, L.; Duscha, V.; Schleich, J.; Diekmann, J. Impacts of the EU Emissions Trading Scheme on the Industrial Competitiveness in Germany; German Federal Environment Agency: Berlin, Germany, 2008.

114. Naegele, H.; Zaklan, A. Does the EU ETS cause carbon leakage in European manufacturing? J. Environ. Econ. Manag. 2019, 93, 125-147. [CrossRef]

115. European Commission. Free Allowances. 2020. Available online: https://ec.europa.eu/clima/policies/ets/ allowances_en (accessed on 18 March 2020).

116. Wehrmann, B. Germany's Steel Industry Needs Political Support to Cope with $\mathrm{CO}_{2}$-Reduction-Opinion. 2020. Available online: https://www.cleanenergywire.org/news/germanys-steel-industry-needs-politicalsupport-cope-co2-reduction-opinion (accessed on 10 February 2020).

117. Kiel Institute of World Economics. Zeit für Eine Neue Industriepolitik? (Report No. 122). 2019. Available online: https://www.ifw-kiel.de/fileadmin/Dateiverwaltung/IfW-Publications/-ifw/Kiel_Policy_Brief/Kiel_ Policy_Brief_122.pdf (accessed on 5 March 2020).

118. American Institute for Contemporary German Studies. The German Industry Strategy 2030: Inconsistent and Dangerous! 2019. Available online: https://www.aicgs.org/2019/05/the-german-industry-strategy-2030inconsistent-and-dangerous/ (accessed on 6 May 2019).

119. Federal Statistical Office of Germany. Production in October 2019: $-1.7 \%$ Seasonally Adjusted on the Previous Month. 2019. Available online: https://www.destatis.de/EN/Press/2019/12/PE19_463_421.html (accessed on 6 April 2020).

120. Canzler, W. Market and Technology Trends for the Automotive Future in Germany. In The Ecological Modernization Capacity of Japan and Germany; Springer: Wiesbaden, Germany, 2020; pp. 155-169.

121. Arnold, M. German Industry Hit by Biggest Downturn Since 2009. Financial Times. 2019. Available online: https://www.ft.com/content/a1a14220-1801-11ea-9ee4-11f260415385 (accessed on 15 March 2020).

122. Malerba, F.; Pisano, G.P. Innovation, competition and sectoral evolution: An introduction to the special section on Industrial Dynamics. Ind. Corp. Chang. 2019, 28, 503-510. [CrossRef]

123. Hummen, T.; Ostertag, K. Consumption trends of steel and aluminium in the context of decarbonization (No. S3/2015). Work. Pap. Sustain. Innov. 2015, 1-20.

124. Stahl. Statistics|Stahl-Online.de-Part 2. 2020. Available online: https://en.stahl-online.de/index.php/ statistics/2/ (accessed on 16 June 2020).

125. International Trade Administration. Steel Exports Report: Germany. 2017. Available online: https: //legacy.trade.gov/steel/countries/pdfs/2017/q2/exports-germany.pdf (accessed on 16 June 2020).

126. Global Wind Energy Council. Global Wind Report 2018. 2019. Available online: https://gwec.net/wp-content/ uploads/2019/04/GWEC-Global-Wind-Report-2018.pdf (accessed on 24 April 2019).

127. VDZ. Cement Markets, Regional Markets and the International Environment. 2020. Available online: https://www.vdz-online.de/en/cement-industry/cement-sector/cementmarkets/ (accessed on 16 June 2020).

128. Supino, S.; Malandrino, O.; Testa, M.; Sica, D. Sustainability in the EU cement industry: The Italian and German experiences. J. Clean. Prod. 2016, 112, 430-442. [CrossRef]

129. Eurostat. Production and International Trade in Chemicals. 2019. Available online: https://ec.europa.eu/eurostat/statistics-explained/index.php/Production_and_international_trade_ in_chemicals\#Growing_trade_in_chemicals (accessed on 3 August 2020).

130. Keller, F.; Lee, R.P.; Meyer, B. Life cycle assessment of global warming potential, resource depletion and acidification potential of fossil, renewable and secondary feedstock for olefin production in Germany. J. Clean. Prod. 2020, 250, 119484. [CrossRef] 
131. Alkousaa, R.; Martin, M. German Chemical Industry Body Slashes 2019 Revenue Forecast. 2019. Reuters. Available online: https://www.reuters.com/article/germany-economy-chemicals/german-chemical-industrybody-slashes-2019-revenue-forecast-idUSS8N23X00I (accessed on 3 July 2020).

132. Stephan, D. Downward Trend Continues: German Chemical Industry Cuts its 2019 Forecast. 2019. Available online: https://www.process-worldwide.com/downward-trend-continues-german-chemical-industry-cutsits-2019-forecast-a-845313/ (accessed on 7 June 2020).

133. Kädtler, J.; Sperling, H.J. After globalisation and financialisation: Logics of bargaining in the German automotive industry. Compet. Chang. 2002, 6, 149-168. [CrossRef]

134. Fischedick, M.; Marzinkowski, J.; Winzer, P.; Weigel, M. Techno-economic evaluation of innovative steel production technologies. J. Clean. Prod. 2014, 84, 563-580. [CrossRef]

135. Khurana, S.; Banerjee, R.; Gaitonde, U. Energy balance and cogeneration for a cement plant. Appl. Therm. Eng. 2002, 22, 485-494. [CrossRef]

136. Luis, P.; Van der Bruggen, B. Exergy analysis of energy-intensive production processes: Advancing towards a sustainable chemical industry. J. Chem. Technol. Biotechnol. 2014, 89, 1288-1303. [CrossRef]

137. Thollander, P.; Ottosson, M. Energy management practices in Swedish energy-intensive industries. J. Clean. Prod. 2010, 18, 1125-1133. [CrossRef]

138. Arens, M.; Worrell, E.; Eichhammer, W.; Hasanbeigi, A.; Zhang, Q. Pathways to a low-carbon iron and steel industry in the medium-term-the case of Germany. J. Clean. Prod. 2017, 163, 84-98. [CrossRef]

139. Arens, M.; Worrell, E.; Schleich, J. Energy intensity development of the German iron and steel industry between 1991 and 2007. Energy 2012, 45, 786-797. [CrossRef]

140. Brunke, J.C.; Blesl, M. Energy conservation measures for the German cement industry and their ability to compensate for rising energy-related production costs. J. Clean. Prod. 2014, 82, 94-111. [CrossRef]

141. Usón, A.A.; López-Sabirón, A.M.; Ferreira, G.; Sastresa, E.L. Uses of alternative fuels and raw materials in the cement industry as sustainable waste management options. Renew. Sustain. Energy Rev. 2013, 23, 242-260. [CrossRef]

142. Bühler, F.; Guminski, A.; Gruber, A.; Nguyen, T.V.; von Roon, S.; Elmegaard, B. Evaluation of energy saving potentials, costs and uncertainties in the chemical industry in Germany. Appl. Energy 2018, 228, 2037-2049. [CrossRef]

143. Erisman, J.W.; Sutton, M.A.; Galloway, J.; Klimont, Z.; Winiwarter, W. How a century of ammonia synthesis changed the world. Nat. Geosci. 2008, 1, 636-639. [CrossRef]

144. Kuntke, P.; Śmiech, K.; Bruning, H.; Zeeman, G.; Saakes, M.; Sleutels, T.H.J.A.; Hamelers, H.V.M.; Buisman, C.J.N. Ammonium recovery and energy production from urine by a microbial fuel cell. Water Res. 2012, 46, 2627-2636. [CrossRef]

145. Hawkesford, M.J. Reducing the reliance on nitrogen fertilizer for wheat production. J. Cereal Sci. 2014, 59, 276-283. [CrossRef]

146. Ghanta, M.; Fahey, D.; Subramaniam, B. Environmental impacts of ethylene production from diverse feedstocks and energy sources. Appl. Petrochem. Res. 2014, 4, 167-179. [CrossRef]

147. Schorcht, F.; Kourti, I.; Scalet, B.M.; Roudier, S.; Sancho, L.D. Best available techniques (BAT) reference document for the production of cement, lime and magnesium oxide. In European Commission Joint Research Centre Institute for Prospective Technological Studies (Report EUR 26129 EN); Publications Office of the European Union: Luxembourg, 2013.

148. Falcke, H.; Holbrook, S.; Clenahan, I.; Carretero, A.L.; Sanalan, T.; Brinkmann, T.; Joze, R.; Benoît, Z.; Serge, R.; Sancho, L.D. Best Available Techniques (BAT) Reference Document for the Production of Large Volume Organic Chemicals; Publications Office of the European Union: Luxembourg, 2017.

149. Kopfle, J.; Hunter, R. Direct reduction's role in the world steel industry. Ironmak. Steelmak. 2008, 35, $254-259$. [CrossRef]

150. Gassmann, O.; Zeschky, M.; Wolff, T.; Stahl, M. Crossing the industry-line: Breakthrough innovation through cross-industry alliances with 'non-suppliers'. Long Range Plan. 2010, 43, 639-654. [CrossRef]

151. Leeson, D.; Mac Dowell, N.; Shah, N.; Petit, C.; Fennell, P.S. A Techno-economic analysis and systematic review of carbon capture and storage (CCS) applied to the iron and steel, cement, oil refining and pulp and paper industries, as well as other high purity sources. Int. J. Greenh. Gas Control 2017, 61, 71-84. [CrossRef] 
152. Dütschke, E.; Wohlfarth, K.; Höller, S.; Viebahn, P.; Schumann, D.; Pietzner, K. Differences in the public perception of CCS in Germany depending on CO2 source, transport option and storage location. Int. J. Greenh. Gas Control 2016, 53, 149-159. [CrossRef]

153. Dütschke, E. What drives local public acceptance-comparing two cases from Germany. Energy Procedia 2011, 4, 6234-6240. [CrossRef]

154. Vögele, S.; Rübbelke, D.; Mayer, P.; Kuckshinrichs, W. Germany's “No" to carbon capture and storage: Just a question of lacking acceptance? Appl. Energy 2018, 214, 205-218. [CrossRef]

155. Lee, R.P. Alternative carbon feedstock for the chemical industry?-Assessing the challenges posed by the human dimension in the carbon transition. J. Clean. Prod. 2019, 219, 786-796. [CrossRef]

156. Forsberg, C.W. Future hydrogen markets for large-scale hydrogen production systems. Int. J. Hydrogen Energy 2007, 32, 431-439. [CrossRef]

157. Schwarze, K.; Posdziech, O.; Kroop, S.; Lapeña-Rey, N.; Mermelstein, J. Green industrial hydrogen via reversible high-temperature electrolysis. Ecs Trans. 2017, 78, 2943. [CrossRef]

158. Vogl, V.; Åhman, M.; Nilsson, L.J. Assessment of hydrogen direct reduction for fossil-free steelmaking. J. Clean. Prod. 2018, 203, 736-745. [CrossRef]

159. Amelang, S. German Industry Needs Policy Trigger for Deep Emission Cuts. 2020. Available online: https: //www.cleanenergywire.org/news/german-industry-needs-policy-trigger-deep-emission-cuts (accessed on 24 April 2020).

160. Spear, B. Iron and steel patents: The sinews of the GB Industrial Revolution. World Pat. Inf. 2019, 58, 101901. [CrossRef]

161. Spear, B. Coal-Parent of the Industrial Revolution in Great Britain: The early patent history. World Pat. Inf. 2014, 39, 85-88. [CrossRef]

162. Dobson, P.; Waterson, M. The competition effects of industry-wide vertical price fixing in bilateral oligopoly. Int. J. Ind. Organ. 2007, 25, 935-962. [CrossRef]

163. Kim, J.W.; Lee, J.Y.; Kim, J.Y.; Lee, H.K. Sources of productive efficiency: International comparison of iron and steel firms. Resour. Policy 2006, 31, 239-246. [CrossRef]

164. Sourisseau, S. The global iron and steel industry: From a bilateral oligopoly to a thwarted monopsony. Aust. Econ. Rev. 2018, 51, 232-243. [CrossRef]

165. Burgess, T.; Hwarng, B.; Shaw, N.; De Mattos, C. Enhancing Value Stream Agility: The UK Speciality Chemical Industry. Eur. Manag. J. 2002, 20, 199-212. [CrossRef]

166. Lampadarios, E. Critical challenges for SMEs in the UK chemical distribution industry. J. Bus. Chem. 2016, $13,17-32$.

167. Department for Business; Energy \& Industrial Strategy. International Comparison of the UK Research Base, 2019. 2019. Available online: https://assets.publishing.service.gov.uk/government/uploads/ system/uploads/attachment_data/file/815400/International_comparison_of_the_UK_research_base_2019. _Accompanying_note.pdf (accessed on 26 July 2020).

168. Her Majesty's Treasury. Budget 2020. 2020. Available online: https://www.gov.uk/government/publications/ budget-2020-documents/budget-2020\#fn:62 (accessed on 26 July 2020).

169. Centre for Global Higher Education. UK Universities Interacting with Industry: Patterns of Research Collaboration and Inter-sectoral Mobility of Academic Researchers. 2017. Available online: https://www. researchcghe.org/perch/resources/publications/wp14.pdf (accessed on 26 July 2020).

170. European Commission. The Industrial Emissions Directive-Environment-European Commission. 2020. Available online: https://ec.europa.eu/environment/industry/stationary/ied/legislation.htm (accessed on 28 May 2020).

171. Trew, A. Spatial takeoff in the first industrial revolution. Rev. Econ. Dyn. 2014, 17, 707-725. [CrossRef]

172. Tradingeconomics. United Kingdom. 2020. Available online: https://tradingeconomics.com/united-kingdom (accessed on 28 May 2020).

173. Shanks, W.; Dunant, C.; Drewniok, M.; Lupton, R.; Serrenho, A.; Allwood, J. How much cement can we do without? Lessons from cement material flows in the UK. Resour. Conserv. Recycl. 2019, 141, 441-454. [CrossRef]

174. Singh, K. Chemistry in Daily Life; PHI Learning Pvt. Ltd.: New Delhi, India, 2012.

175. USGS. Cement Statistics and Information. 2020. Available online: https://www.usgs.gov/centers/nmic/ cement-statistics-and-information (accessed on 26 May 2020). 
176. Griffin, P.; Hammond, G. Analysis of the potential for energy demand and carbon emissions reduction in the iron and steel sector. Energy Procedia 2019, 158, 3915-3922. [CrossRef]

177. Millward-Hopkins, J.; Zwirner, O.; Purnell, P.; Velis, C.; Iacovidou, E.; Brown, A. Resource recovery and low carbon transitions: The hidden impacts of substituting cement with imported 'waste' materials from coal and steel production. Glob. Environ. Chang. 2018, 53, 146-156. [CrossRef]

178. Langley, K.F. Energy efficiency in the UK iron and steel industry. Appl. Energy 1986, 23, 73-107. [CrossRef]

179. Griffin, P.; Hammond, G. Industrial energy use and carbon emissions reduction in the iron and steel sector: A UK perspective. Appl. Energy 2019, 249, 109-125. [CrossRef]

180. WSP; Parsons Brinckerhoff; DNV-GL. Industrial Decarbonisation \& Energy Efficiency Roadmaps to 2050 Cement. Report for the Department of Energy and Climate Change and the Department for Business, Innovation and Skills. 2015. Available online: https://assets.publishing.service.gov.uk/government/uploads/ system/uploads/attachment_data/file/416674/Cement_Report.pdf (accessed on 5 March 2020).

181. WSP; Parsons Brinckerhoff; DNV-GL. Industrial Decarbonisation \& Energy Efficiency Roadmaps to 2050 Cross-Sector Summary. Report for the Department of Energy and Climate Change and the Department for Business, Innovation and Skills. 2015. Available online: https://assets.publishing.service.gov.uk/government/ uploads/system/uploads/attachment_data/file/419912/Cross_Sector_Summary_Report.pdf (accessed on 20 March 2020).

182. Mirasgedis, S.; Hontou, V.; Georgopoulou, E.; Sarafidis, Y.; Gakis, N.; Lalas, D.; Loukatos, A.; Gargoulas, N.; Mentzis, A.; Economidis, D.; et al. Environmental damage costs from airborne pollution of industrial activities in the greater Athens, Greece area and the resulting benefits from the introduction of BAT. Environ. Impact Assess. Rev. 2008, 28, 39-56. [CrossRef]

183. He, K.; Wang, L. A review of energy use and energy-efficient technologies for the iron and steel industry. Renew. Sustain. Energy Rev. 2017, 70, 1022-1039. [CrossRef]

184. Cormos, A.; Cormos, C. Reducing the carbon footprint of cement industry by post-combustion $\mathrm{CO}_{2}$ capture: Techno-economic and environmental assessment of a CCS project in Romania. Chem. Eng. Res. Des. 2017, 123, 230-239. [CrossRef]

185. Stockford, C.; Brandon, N.; Irvine, J.; Mays, T.; Metcalfe, I.; Book, D.; Ekins, P.; Kucernak, A.; Molkov, V.; Steinberger-Wilckens, R.; et al. H2FC SUPERGEN: An overview of the Hydrogen and Fuel Cell research across the UK. Int. J. Hydrogen Energy 2015, 40, 5534-5543. [CrossRef]

186. Stenberg, V.; Rydén, M.; Mattisson, T.; Lyngfelt, A. Exploring novel hydrogen production processes by integration of steam methane reforming with chemical-looping combustion (CLC-SMR) and oxygen carrier aided combustion (OCAC-SMR). Int. J. Greenh. Gas Control 2018, 74, 28-39. [CrossRef]

187. Unruh, G.C. Escaping carbon lock-in. Energy Policy 2002, 30, 317-325. [CrossRef]

188. Brown, M.A.; Chandler, J.; Lapsa, M.V.; Sovacool, B.K. Carbon Lock-in: Barriers to Deploying Climate Change Mitigation Technologies (No. ORNL/TM-2007/124); Oak Ridge National Lab. (ORNL): Oak Ridge, TN, USA; Georgia Inst. of Technology: Atlanta, GA, USA, 2008.

189. Lehmann, P.; Creutzig, F.; Ehlers, M.H.; Friedrichsen, N.; Heuson, C.; Hirth, L.; Pietzcker, R. Carbon lock-out: Advancing renewable energy policy in Europe. Energies 2012, 5, 323-354. [CrossRef]

190. Tvaronavičius, V.; Tvaronavičiene, M. Role of fixed investments in economic growth of country: Lithuania in European context. J. Bus. Econ. Manag. 2008, 9, 57-64. [CrossRef]

191. Haskel, J.; Wallis, G. Public support for innovation, intangible investment and productivity growth in the UK market sector. Econ. Lett. 2013, 119, 195-198. [CrossRef]

192. Buschmann, P.; Oels, A. The overlooked role of discourse in breaking carbon lock-in: The case of the German energy transition. Wiley Interdiscip. Rev. Clim. Chang. 2019, 10, e574. [CrossRef]

193. Bugeaud, F.; Pietyra, P.; Liger, V. From Service Design to Innovation through Services: Emergence of a Methodological and Systemic Framework. In Working Conference on Virtual Enterprises; Springer: Berlin/Heidelberg, Germany, 2013; pp. 431-438.

194. Parker, R.; Cox, S. The state and the extractive industries in Australia: Growth for whose benefit? Extr. Ind. Soc. 2020, 7, 621-627. [CrossRef]

195. García-Cabrera, A.; Durán-Herrera, J.; Suárez-Ortega, S. Multinationals' political activity for institutional change: Evidence from Spain during the international crisis of 2008. Eur. Manag. J. 2019, 37, 541-551. [CrossRef] 
196. Pfeifer, S.; Gordon, S.; Pooler, M. Is the UK's New Industrial Strategy Starting to Work? Financial Times. 2018. Available online: https://www.ft.com/content/bb242140-ef2b-11e8-89c8-d36339d835c0 (accessed on 26 May 2020).

197. Partington, R. Watchdog Attacks Tories for 'Neglecting Industrial Strategy'. The Guardian. 2020. Available online: https://www.theguardian.com/politics/2020/feb/19/watchdog-attacks-tories-for-neglectingindustrial-strategy-boris-johnson-uk-economy (accessed on 19 March 2020).

198. Weng, Q.; Xu, H. A review of China's carbon trading market. Renew. Sustain. Energy Rev. 2018, 91, 613-619. [CrossRef]

199. Crompton, P.; Lesourd, J. Economies of scale in global iron-making. Resour. Policy 2008, 33, 74-82. [CrossRef]

200. Worrell, E.; Biermans, G. Move over! Stock turnover, retrofit and industrial energy efficiency. Energy Policy 2005, 33, 949-962. [CrossRef]

201. Dawood, F.; Anda, M.; Shafiullah, G.M. Hydrogen production for energy: An overview. Int. J. Hydrogen Energy 2020, 45, 3847-3869. [CrossRef]

202. Mao, X.; He, C. A trade-related pollution trap for economies in transition? Evidence from China. J. Clean. Prod. 2018, 200, 781-790. [CrossRef]

203. Latorre, M.C.; Olekseyuk, Z.; Yonezawa, H. Trade and foreign direct investment-related impacts of Brexit. World Econ. 2020, 43, 2-32. [CrossRef]

204. Jafari, Y.; Britz, W. Brexit: An economy-wide impact assessment on trade, immigration, and foreign direct investment. Empirica 2020, 47, 17-52. [CrossRef]

205. Davies, R. British Steel Rescue: UK Extends Funding ahead of Decision on Jingye. The Guradian. 2020. Available online: https://www.theguardian.com/business/2020/feb/28/british-steel-rescue-uk-extendsfunding-ahead-of-decision-on-jingye (accessed on 28 March 2020).

206. Johnson, B.H.; Charles, E.; Hommen, L.; Lemola, T.; Malerba, F.; Reiss, T.; Smith, K. The ISE Policy Statement: The Innovation Policy Implications of the ISE Research Project; VBN: Aalborg, Denmark, 1998.

207. Pisano, G. Profiting from innovation and the intellectual property revolution. Res. Policy 2006, 35, 1122-1130. [CrossRef]

208. Borghesi, S.; Cainelli, G.; Mazzanti, M. Linking emission trading to environmental innovation: Evidence from the Italian manufacturing industry. Res. Policy 2015, 44, 669-683. [CrossRef]

209. Kuik, O.; Hofkes, M. Border adjustment for European emissions trading: Competitiveness and carbon leakage. Energy Policy 2010, 38, 1741-1748. [CrossRef]

210. Vögele, S.; Grajewski, M.; Govorukha, K.; Rübbelke, D. Challenges for the European steel industry: Analysis, possible consequences and impacts on sustainable development. Appl. Energy 2020, 264, 114633. [CrossRef]

211. Walz, R. Towards a dynamic understanding of innovation systems: An integrated TIS-MLP approach for wind turbines. In New Developments in Eco-Innovation Research; Springer: Cham, Switzerland, 2018; pp. 277-295.

212. Mazur, C.; Contestabile, M.; Offer, G.J.; Brandon, N.P. Assessing and comparing German and UK transition policies for electric mobility. Environ. Innov. Soc. Transit. 2015, 14, 84-100. [CrossRef]

213. Wagner, O.; Adisorn, T.; Tholen, L.; Kiyar, D. Surviving the Energy Transition: Development of a Proposal for Evaluating Sustainable Business Models for Incumbents in Germany's Electricity Market. Energies 2020, 13, 730. [CrossRef]

214. Bukovszki, V.; Magyari, Á.; Braun, M.K.; Párdi, K.; Reith, A. Energy Modelling as a Trigger for Energy Communities: A Joint Socio-Technical Perspective. Energies 2020, 13, 2274. [CrossRef]

215. Miedema, J.H.; Van der Windt, H.J.; Moll, H.C. Opportunities and barriers for biomass gasification for green gas in the dutch residential sector. Energies 2018, 11, 2969. [CrossRef]

216. Doukas, H.; Nikas, A. Decision support models in climate policy. Eur. J. Oper. Res. 2020, 280, 1-24. [CrossRef]

217. Doukas, H.; Nikas, A.; González-Eguino, M.; Arto, I.; Anger-Kraavi, A. From integrated to integrative: Delivering on the Paris Agreement. Sustainability 2018, 10, 2299. [CrossRef]

218. Nikas, A.; Lieu, J.; Sorman, A.; Gambhir, A.; Turhan, E.; Vienni Baptista, B.; Doukas, H. The desirability of transitions in demand: Incorporating behavioural and societal transformations into energy modelling. Energy Res. Soc. Sci. 2020, 70, 101780. [CrossRef]

219. Van Sluisveld, M.A.; Hof, A.F.; Carrara, S.; Geels, F.W.; Nilsson, M.; Rogge, K.; Turnheim, B.; van Vuuren, D.P. Aligning integrated assessment modelling with socio-technical transition insights: An application to low-carbon energy scenario analysis in Europe. Technol. Forecast. Soc. Chang. 2018, 151, 119177. [CrossRef] 
220. Rogge, K.S.; Pfluger, B.; Geels, F.W. Transformative policy mixes in socio-technical scenarios: The case of the low-carbon transition of the German electricity system (2010-2050). Technol. Forecast. Soc. Chang. 2018, 151, 119259. [CrossRef]

221. Geels, F.W.; McMeekin, A.; Pfluger, B. Socio-technical scenarios as a methodological tool to explore social and political feasibility in low-carbon transitions: Bridging computer models and the multi-level perspective in UK electricity generation (2010-2050). Technol. Forecast. Soc. Chang. 2018, 151, 119258. [CrossRef]

222. Bachner, G.; Wolkinger, B.; Mayer, J.; Tuerk, A.; Steininger, K.W. Risk assessment of the low-carbon transition of Austria's steel and electricity sectors. Environ. Innov. Soc. Transit. 2018, 35, 309-332. [CrossRef]

223. Vögele, S.; Rübbelke, D.; Govorukha, K.; Grajewski, M. Socio-technical scenarios for energy-intensive industries: The future of steel production in Germany. Clim. Chang. 2019. [CrossRef]

224. Nikas, A.; Stavrakas, V.; Arsenopoulos, A.; Doukas, H.; Antosiewicz, M.; Witajewski-Baltvilks, J.; Flamos, A. Barriers to and consequences of a solar-based energy transition in Greece. Environ. Innov. Soc. Transit. 2020, 35, 383-399. [CrossRef]

225. Antosiewicz, M.; Nikas, A.; Szpor, A.; Witajewski-Baltvilks, J.; Doukas, H. Pathways for the transition of the Polish power sector and associated risks. Environ. Innov. Soc. Transit. 2020, 35, 271-291. [CrossRef]

226. United Nations. International Standard Industrial Classification of All Economic Activities (Isic) Rev. 4; United Nations Publishing: New York, NY, USA, 2008.

227. World Steel Association. About Steel. 2020. Available online: https://www.worldsteel.org/about-steel.html (accessed on 28 May 2020).

228. Eurofer. European Steel in Figures 2019. 2019. Available online: http://www.eurofer.org/News\%26Events/ PublicationsLinksList/201907-SteelFigures.pdf (accessed on 10 April 2020).

229. Razzaq, R.; Li, C.; Zhang, S. Coke oven gas: Availability, properties, purification, and utilization in China. Fuel 2013, 113, 287-299. [CrossRef]

230. Geerdes, M.; Chaigneau, R.; Kurunov, I. Modern blast furnace ironmaking: An introduction (2015); Ios Press: Amsterdam, The Netherlands, 2015.

231. Orth, A.; Anastasijevic, N.; Eichberger, $\mathrm{H}$. Low $\mathrm{CO}_{2}$ emission technologies for iron and steelmaking as well as titania slag production. Miner. Eng. 2007, 20, 854-861. [CrossRef]

232. Anameric, B.; Kawatra, S.K. Direct iron smelting reduction processes. Miner. Process. Extr. Metall. Rev. 2008, 30, 1-51. [CrossRef]

233. Xiaoguang, Y.; Wanren, X.; Shaobo, Z. Theoretic Analysis on Using Top Gas-recycle and Coal-injection Technologies to Reduce Fuel Consumption of COREX/FINEX Process. Baosteel Technol. 2008, 6, 23-28.

234. Yüksel, İ. A review of steel slag usage in construction industry for sustainable development. Environ. Dev. Sustain. 2017, 19, 369-384. [CrossRef]

235. Proctor, D.M.; Fehling, K.A.; Shay, E.C.; Wittenborn, J.L.; Green, J.J.; Avent, C.; Bigham, R.D.; Connolly, M.; Lee, B.; Shepker, T.O.; et al. Physical and chemical characteristics of blast furnace, basic oxygen furnace, and electric arc furnace steel industry slags. Environ. Sci. Technol. 2000, 34, 1576-1582. [CrossRef]

236. Worrell, E. Cement and Energy. Reference Module in Earth Systems and Environmental Sciences; Elsevier: Amsterdam, The Netherlands, 2014.

237. Hurley, P.; Pritchard, R. CEMENT. Encycl. Anal. Sci. 2005, 21, 458-463.

238. Hannant, D.; Venkata Siva, S.; Sreekanth, P.R. 5.15 Cement-Based Composites. In Comprehensive Composite Materials II; Elsevier: Amsterdam, The Netherlands, 2018; pp. 379-420.

239. Oliveira, F.; Fernandes, J.; Galindo, J.; Rodríguez, J.; Cañadas, I.; Vermelhudo, V.; Nunes, A.; Rosa, L. Portland cement clinker production using concentrated solar energy-A proof-of-concept approach. Sol. Energy 2019, 183, 677-688. [CrossRef]

(C) 2020 by the authors. Licensee MDPI, Basel, Switzerland. This article is an open access article distributed under the terms and conditions of the Creative Commons Attribution (CC BY) license (http://creativecommons.org/licenses/by/4.0/). 